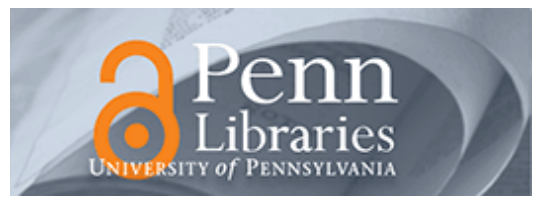

University of Pennsylvania

ScholarlyCommons

Marketing Papers

Wharton Faculty Research

\title{
2-2017
}

\section{Drip Pricing When Consumers Have Limited Foresight: Evidence from Driving School Fees}

\author{
Katja Seim \\ University of Pennsylvania \\ Maria Ana Vitorino \\ David M. Muir
}

Follow this and additional works at: https://repository.upenn.edu/marketing_papers

Part of the Business Administration, Management, and Operations Commons, Business Analytics Commons, Business Intelligence Commons, Management Sciences and Quantitative Methods Commons, Marketing Commons, and the Sales and Merchandising Commons

\section{Recommended Citation}

Seim, K., Vitorino, M. A., \& Muir, D. M. (2017). Drip Pricing When Consumers Have Limited Foresight: Evidence from Driving School Fees. http://dx.doi.org/10.2139/ssrn.2220986

This is an unpublished manuscript.

This paper is posted at ScholarlyCommons. https://repository.upenn.edu/marketing_papers/347

For more information, please contact repository@pobox.upenn.edu. 


\title{
Drip Pricing When Consumers Have Limited Foresight: Evidence from Driving School Fees
}

\begin{abstract}
This paper empirically investigates the add-on or "drip" pricing behavior of firms. We present a model in which consumers purchase a base product and, with some probability, an add-on product from the same firm, but are not always attentive to their possible need for the add-on product. We show that a loss leader pricing strategy emerges whereby firms price the base product below, and the add-on above, standalone pricing levels. We test the implications of the model in the Portuguese market for driving instruction where students frequently pay for repeat driving exams and additional lessons upon failing their initial exam. Relying on a detailed, nationwide data set on student characteristics and preferences, school attributes including fees and costs, and market demographics for a cross-section of local markets with differing numbers of school competitors, we find evidence in support of the model predictions. Most notably, prices for the base course of instruction, but not the add-on repeat courses, decline in the number of competitors a firm faces. We complement these results with survey evidence on possible sources of consumer inattention that the observational data does not speak to. The consumer survey suggests that approximately one quarter of students are inattentive to repeat fees when making their school choice driven both by an underestimation of fail propensities and an unawareness of the actual cost of a repeat exam. This result has important policy implications regarding the cross-subsidization of students who are aware of the add-on by those who are not.
\end{abstract}

\section{Keywords}

add-on pricing, market structure, loss-leader pricing, inattentive consumers

\section{Disciplines}

Business | Business Administration, Management, and Operations | Business Analytics | Business Intelligence | Management Sciences and Quantitative Methods | Marketing | Sales and Merchandising

\section{Comments}

This is an unpublished manuscript. 


\title{
Drip Pricing When Consumers Have Limited Foresight: Evidence from Driving School Fees*
}

\author{
Current Version: February 2017
}

\author{
Katja Seim ${ }^{\dagger} \quad$ Maria Ana Vitorino David M. Muir $^{\S}$
}

\begin{abstract}
This paper empirically investigates the add-on or "drip" pricing behavior of firms. We present a model in which consumers purchase a base product and, with some probability, an add-on product from the same firm, but are not always attentive to their possible need for the add-on product. We show that a loss leader pricing strategy emerges whereby firms price the base product below, and the add-on above, standalone pricing levels. We test the implications of the model in the Portuguese market for driving instruction where students frequently pay for repeat driving exams and additional lessons upon failing their initial exam. Relying on a detailed, nationwide data set on student characteristics and preferences, school attributes including fees and costs, and market demographics for a cross-section of local markets with differing numbers of school competitors, we find evidence in support of the model predictions. Most notably, prices for the base course of instruction, but not the add-on repeat courses, decline in the number of competitors a firm faces. We complement these results with survey evidence on possible sources of consumer inattention that the observational data does not speak to. The consumer survey suggests that approximately one quarter of students are inattentive to repeat fees when making their school choice driven both by an underestimation of fail propensities and an unawareness of the actual cost of a repeat exam. This result has important policy implications regarding the cross-subsidization of students who are aware of the add-on by those who are not.
\end{abstract}

Keywords: add-on pricing, market structure, loss-leader pricing, inattentive consumers

\footnotetext{
${ }^{*}$ We thank Susana Paulino at Instituto da Mobilidade e dos Transportes for access to the data and information about the industry. Ana Isabel Horta provided excellent research assistance, and Susana Belo assisted with local data collection. We thank the participants of the Marketing Science conference, the Annual Federal Trade Commission Microeconomics Conference, the QME Conference, the UT Dallas FORMS conference, the NBER Industrial Organization Meeting, the IIOC conference, the AEA Annual Meeting, and seminar participants at the Portuguese Competition Authority, Erasmus University, Tilburg University, Stanford University, Penn State University, and the UCLA Anderson School of Management for their comments. We have benefitted greatly from comments by Frederico Belo, Mark Bergen, Chris Conlon, Glenn Ellison, Michael Grubb, Thomas Holmes, Kanishka Misra, Amil Petrin, Stephan Seiler, Enno Siemsen, Venkatesh Shankar, Mariano Tappata, and Joel Waldfogel. We gratefully acknowledge support from the Office of the Vice President for Research at the University of Minnesota and from the Global Initiatives Research Center at the University of Pennsylvania. All errors are our own.

${ }^{\dagger}$ University of Pennsylvania and NBER, kseim@wharton.upenn.edu.

${ }^{\ddagger}$ University of Minnesota, vitorino@umn.edu.

${ }^{\S}$ University of Delaware, muir@udel.edu.
} 


\section{Introduction}

In many industries, sellers charge a low price for an upfront product in hopes of generating subsequent sales of other "add-on" products in greater numbers or at greater profit margins than the upfront product's. This pricing strategy is commonly referred to as "drip-pricing" 1 Rationalactor models typically explain the notion that multi-product firms might sell some products as low-markup "bargains" or loss leaders, only to recover these losses with high-markup "ripoffs" with search costs, price discrimination, or switching costs.2 Gabaix and Laibson (2006) formalize another explanation for high markups in add-on markets: they may be optimal when some consumers are unaware of the contingent charge for the unadvertised add-on product, or its likely magnitude 3 As an example, they point to tied products such as printers and toner cartridges in which consumer unawareness of the cartridge's high markup reduces the role that the tied product plays in the purchase process 4 Such pricing strategies have been the basis for several recent lawsuits, including event ticket order processing fees and the charging of "internet taxes" for internet access (see Ticketmaster's 2015 settlement in a class action lawsuit alleging that the company failed to disclose pertinent aspects of its shipping and order processing fee structure, and AT\&T Mobility's 2011 settlement in a lawsuit centered on its charging consumers for taxes, fees and surcharges on internet access under its data plans).

To what extent are the theoretical predictions about add-on pricing borne out in practice? The empirical literature on add-on pricing is scant. Some work provides evidence on the incidence of add-on charges and documents high prices in tied aftermarkets consistent with the predictions of theoretical models of add-on pricing. For example, Ellison and Ellison (2009) show that a loss leader firm that shrouds add-ons is profitable by attracting a large number of customers who end

\footnotetext{
${ }^{1}$ According to the Federal Trade Commission (FTC), "Drip pricing is a pricing technique in which firms advertise only part of a product's price and reveal other charges later as the customer goes through the buying process. The additional charges can be mandatory charges, such as hotel resort fees, or fees for optional upgrades and add-ons. Drip pricing is used by many types of firms, including internet sellers, automobile dealers, financial institutions, and rental car companies" (https://www.ftc.gov/news-events/events-calendar/2012/05/economics-drip-pricing).

${ }^{2}$ See Ellison (2005) for a general framework that intersects these three explanations.

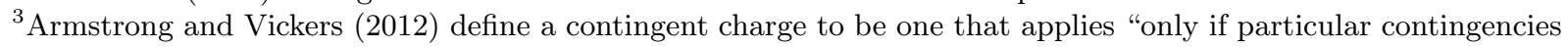
arise and that often catch customers unaware, either because they did not know of the fee and/or that the triggering event would happen."

4 Gabaix and Laibson (2006)'s work and significant extensions thereof (see e.g., Bordalo et al. 2013 and Heidhues et al. 2016) are related to a broader literature that explores how biases in consumers' beliefs explain various pricing practices. Particular features of subscription pricing are consistent with quasi-hyperbolic discounting (Oster and Scott Morton 2005, DellaVigna and Malmendier 2006), lack of self control (DellaVigna and Malmendier 2004) or overconfidence (Grubb 2009); loss aversion might motivate bait-and-switch pricing (Köszegi and Rabin 2006 | Heidhues and Köszegi 2010); and boundedly-rational heuristics can be applied to study how market equilibria exploit noise in consumer product evaluations (Jin and Leslie 2003 , Spiegler 2006).
} 
up buying upgraded products at higher prices. In a field experiment, Chetty et al. $(2009)$ find that demand falls when retailers post tax-inclusive prices (i.e., disclose surcharges) for personal care products. Hossain and Morgan (2006) and Brown et al. (2010) demonstrate that raising shipping charges increases revenues in eBay auctions. In the context of retail banking, Armstrong and Vickers (2012) provide evidence and a behavioral model of the incidence of overdraft fees and consumer inattention in the UK, and Stango and Zinman (2009, 2014) document the incidence and magnitude of overdraft fees in the US, together with estimates of the share of such fees that could have been avoided had customers paid greater attention to their finances. Stango and Zinman (2014) and Alan et al. (2015) find that providing information about overdraft costs reduces overdraft usage, thus suggesting the possibility of intervention to decrease consumer inattention.

While some of the latter papers provide evidence of add-on pricing in the spirit of Gabaix and Laibson (2006) by documenting a response in the size of the add-on market to a reduction in consumer inattention, there is no quantification of the role of the competitive environment in affecting upfront and add-on prices and profit margins, and of the division of firm profit between the two product markets. In this paper, we complement the existing literature in studying addon pricing in a consumer service setting where we observe a variety of market structures across different localities, ranging from highly concentrated markets to ones with numbers of competitors that earlier work found to be more than sufficient to yield near perfectly competitive margins for similar local services (see, e.g., Bresnahan and Reiss 1991 and Asplund and Sandin 1999). This allows us to investigate whether the conclusion of the theory literature that supranormal prices and markups can prevail for the add-on, but not the base, product in competitive markets is borne out in our setting, relative to the benchmark provided by prices in the more concentrated subset of markets.

A challenge that our observational data shares with other work is that it is difficult to disentangle sources of consumer inattention using their consumption behavior alone. Some work has therefore investigated different explanations for consumers' limited responses to add-on charges using survey evidence (e.g., Armstrong and Vickers 2012, Chetty et al. 2009). There is, however, no empirical evidence validating the sources of consumer inattention with actual demand responses. To fill this gap, we conduct a consumer survey and link consumers' survey responses to their later add-on consumption, which allows us to compare their own expectations of use and their actual use of the add-on.

We investigate add-on pricing in the Portuguese market for driving instruction. Here students 
initially purchase a base course of driving instruction, completion of which entitles them to one attempt at passing a theory and an on-road driving exam. Should the student fail either exam, new fees accrue for additional lessons and a repeat exam, the add-on service in this context. There are a number of reasons why students may be inattentive to repeat fees. First, while schools are required to keep a full schedule of their repeat fees on site, they are not required to inform students about their pricing structure at the time of registration. Second, as with professional testing and certification markets more generally, we show using our newly collected survey evidence that consumers systematically underestimate their probability of failing an exam and, thus, their demand for the add-on.5 This is despite the fact that exam repetition, i.e., add-on usage, is common; 44.2 percent of students fail either the theory or the on-road exam the first time.

A unique feature of our setting is that we rely on novel administrative data for the universe of Portuguese driving school students over a three-year period, including information on the school they attend, the sequence of their exam outcomes, and demographic information such as their age, gender, and place of residence. We combine these data with information on school characteristics and hand-collected school fees for the basic driving course and for the theory and the on-road repeat courses. We also exploit the simplicity of the firms' cost structure, together with data on school-specific cost shifters, to estimate the per-student cost to the school for the basic and repeat courses and profit margins for schools' upfront and add-on services. Taken together, these data allow us to trace the entire sequence of purchases that students make, the prices they pay for each purchase, and the role of the competitive environment on pricing and markups.

Beyond the availability of highly detailed consumer data, our setting has a number of distinct advantages for studying the prevalence and pricing of add-on purchases. First, in most settings, it is difficult to disentangle ex-ante planned add-on consumption from unexpected, surprise purchases ${ }^{6}$ In our setting, in contrast, the consumer - the student - does not derive independent utility from the repeat course; it is reasonable to assume all students would prefer to pass the driving exam at first try and would not purchase the add-on if they did. Ex-ante purchase intentions are thus likely nonexistent. Second, regulatory restrictions on transferring already completed lessons across schools result in high switching costs and very infrequent school switches. The repeat course of instruction

\footnotetext{
${ }^{5}$ In consumer financial markets, consumers might similarly underestimate their future need for account features such as overdraft services or financing at the time when they open a bank or credit card account (Stango and Zinman 2009).

${ }^{\circ}$ For example, with observational data on airline purchases it is impossible to separate which consumers had planned to pay for baggage fees from those who were surprised by such fees once they arrive at the airport. The same applies to mini-bar purchases made at a hotel.
} 
is thus a classic example of a tied aftermarket where the student purchases the repeat course from his existing school. At the same time, the schools do not use bundling strategies to sell the two products or negotiate over prices with students. Third, the fact that obtaining a driver's license is a one-time event means that students cannot rely on repeat purchases to learn about pricing or their individual likelihood of failing an exam. Demand does not exhibit state dependence. Last, investigating the role of market structure on pricing strategies is challenging in observational studies because market structure is an endogenous equilibrium outcome. We exploit the availability of cost measures and information on prior entry regulations as instruments to identify the effect of the number of competitors on price.

To study firms' pricing, we set up a model that builds on the Gabaix and Laibson (2006) model of add-on pricing with inattentive consumers. On the demand side, we allow for two types of consumers who purchase an upfront and, with some probability, an add-on product from horizontally differentiated firms. Sophisticated consumers are rational in forming expectations about their likelihood of needing to purchase the add-on and can engage in costly effort to reduce their purchase incidence. Inattentive consumers, conversely, do not account for the add-on and their likelihood of requiring it when choosing their school. We show that a typical loss-leader pricing strategy emerges in which firms sell the upfront product below competitive profit margins and simultaneously price the add-on at monopoly levels.

As in Gabaix and Laibson, the assumption of differentiated Bertrand competition among symmetric firms results in profit neutrality across the two products, with add-on profits offsetting upfront losses. This feature has two consequences for the upfront product's price. First, a larger share of inattentive consumers, who unexpectedly (to them) participate and generate profit in the add-on market, depresses the upfront product's price. Second, an increase in the probability with which consumers require the add-on product similarly raises profitability, offset by a lower upfront product price and markup.

We test several of these predictions in the driving school setting. First, we establish that the rates of failure across schools result in significant revenue and estimated profit to schools from the add-on market; our data indicate that an estimated 16.8 percent of revenue and 32.6 percent of variable profit derive from repeat courses for the median school.

Second, while the percent markup for the base course averages 27.2 percent, the corresponding figures for the add-on market are significantly higher: 86.4 and 57.5 percent in the theory and on-road add-on markets, respectively. Schools' upfront prices and markups also strongly correlate 
with the number of schools in their municipality, pointing to the standard downward pressure on prices of additional competition. On the other hand, schools' repeat fees and markups do not correlate significantly with the number of competitors, as predicted by the theoretical model.

Our theoretical model is agnostic regarding the reasons behind consumers' limited foresight. Similarly, our administrative data do not contain direct evidence on students' ex-ante perception of either their likelihood of failing or their understanding of the financial repercussions of having to retake the exams. We therefore conduct a survey of a representative sample of students as part of their theory exam session at a select testing center. We then link the students' responses to their exam performance on the subsequent theory and on-road exams. Our survey-based analysis is novel in that it provides us with the ex-ante expectations of add-on consumption that would affect the initial provider choice, rather than inquiring about determinants of such consumption after it has occurred. Linking such ex-ante expectations to ex-post behavior allows us to disentangle inattention due to overoptimism from price unawareness, which is relevant for any policy intervention geared at improving consumer information about the add-on. Further, the survey provides us with a measure of effort that allows us to test whether sophisticated consumers engage in more effort than inattentive ones, as predicted by the theory model.

The survey evidence suggests that inattention is a plausible explanation for the fee structure in the industry: we identify a sizable group of students - 22 percent - who either believe they do not need to or do not know whether they need to pay for retaking an exam. The survey evidence also suggests that students overestimate their probabilities of passing the future on-road exam. Unawareness of price and misassessment of fail propensities are two reasons why students would not respond to the price of the add-on at the time of their school choice, thus suggesting that the share of inattentive students in the market exceeds 22 percent. The survey also shows that informed students engage in more effort to prepare for the driving exam, thereby reducing the probability of having to purchase the add-on service, consistent with the theoretical model.

That inattentive students constitute a nontrivial subset of the student population has important distributional consequences. If sophisticated students can reduce their demand in the add-on market, they reap the benefits of low prices in the upfront market. Thus, inattentive students - whose business in both markets comprises a significant portion of schools' profits - effectively subsidize the remaining students with lower prices in the upfront market. Such distributional effects would be particularly concerning if inattentive students are comprised of demographically vulnerable population segments. While we do not formally evaluate these welfare implications, our evidence points 
to a number of potential avenues for regulators might engage in to combat students' inattention, including improving consumer understanding of pass rates via pass rate disclosures and enforcing that schools post up-to-date, easy to compare complete pricing menus. Beyond the particular market we study and the issues it raises, understanding add-on pricing is important for a variety of policy questions, ranging from consumer protection measures, given the potentially deceptive nature of add-on pricing, to tax incidence and optimal taxation, to antitrust questions, assessing, for example, whether add-on pricing facilitates tacit collusion on the price of the add-on.

The paper proceeds as follows. Section 2 presents a model of add-on pricing with inattentive consumers. Section 3 introduces the data and the institutional setting of Portuguese driving schools. Section 4 and Section 5 provide evidence to support some of the assumptions and predictions of the model based on observational and survey data, while Section 6 discusses alternative interpretations and robustness checks. Section 7 concludes.

\section{A Model of Add-on Pricing with Inattentive Students}

We present a stylized model of add-on pricing in the spirit of Gabaix and Laibson (2006) and Spiegler (2011) to illustrate that the loss-leader pricing strategies common to multi-product settings with search or switching costs can also arise when consumers are inattentive to their demand for the add-on product. We develop the model for our empirical setting of driving instruction, but the model can be reinterpreted for other contexts in which consumers purchase an upfront and add-on products and some consumers are inattentive to their demand for the add-on products.

Because our setting does not map directly into the existing theoretical add-on models, we adapt the theory of Gabaix and Laibson to allow us to test the model using in our empirical context. There are two main differences between our model and the model in Gabaix and Laibson (2006). First, we model the add-on consumption as a probabilistic outcome. Second, firms do not make an explicit "shrouding" decision, as in Armstrong and Vickers (2012).7

Consider a market with $n$ symmetric schools and a continuum of students. The schools offer an upfront or base service $u$ - a course of instruction to prepare for the driving exam - and an add-on service $a$ - a make-up course for exam re-takers. Firms face constant and nonnegative marginal costs of providing each service, $\left(c^{u}, c^{a}\right)$. Students then choose a school to enroll in and purchase

\footnotetext{
${ }^{7}$ We formulate a model without shrouding, since in our empirical setting, add-on charges are not prominently advertised but also not hidden. Similarly, in the context of contingent overdraft charges studied by Armstrong and Vickers (2012), charges are not hidden but not prominently displayed in the banks' marketing materials.
} 
the upfront service $u$. We assume that the add-on price takes the form of a surcharge: students who fail the exam do not have a choice but to purchase the add-on. As in classic repeat purchase models of pricing with switching costs (Klemperer 1987a; Beggs and Klemperer 1992; Farrell and Klemperer 2007), we assume that consumers are locked into purchasing both the upfront course and a possible repeat course from the same driving school 8 In contrast to these models where firms are not able to commit to prices for subsequently purchased add-on products in the initial period, firms are required to keep at hand a full schedule of prices. We thus assume that schools commit to the add-on price when setting the price menu in the initial stage of the game.

In period 1 , each school $j$ simultaneously chooses and commits to a pricing strategy $\left(p_{j}^{u}, p_{j}^{a}\right)$, where $p_{j}^{u}$ and $p_{j}^{a}$ are the prices of school $j$ 's upfront and add-on services $9^{9}$ As in Gabaix and Laibson (2006), the add-on price $p^{a}$ is effectively bounded above by $\bar{p}^{a}$. For example, if a student is forced to pay a high repeat-course price, he might choose not to continue with driving instruction or lodge a complaint with the regulatory body, the IMT. While the IMT does not directly regulate the price of repeat courses, its oversight likely also limits the fees that schools can charge. In period 2, students learn whether or not they need to buy the add-on at its set price depending on their exam results from period 1 . Students have a strictly positive, identical probability of $\bar{\lambda} \in(0,1]$ of failing the initial driving exam.

We assume that there are two student types in the market: a share of $\pi \in(0,1)$ sophisticated types $s$ and $(1-\pi)$ inattentive types $m$. In period one, the inattentive type disregards the add-on service; they only become aware of it ex post when they fail the exam and are forced to purchase it. This assumption might reflect that inattentive students underestimate their probability of failing the exam - that these students suffer from over-optimism, for example - or that students are unaware of repeat course fees simply because the school does not prominently advertise this information.

Our definition of limited attention is close to Armstrong and Vickers s (2012) who similarly attribute inattentiveness either to the knowledge of the fees or/and an incorrect assessment of the probability of incurring the add-on fee 10

\footnotetext{
${ }^{8}$ We discuss below that we observe a negligible share of school transfers by students in our data, which motivates the lock-in assumed here.

${ }^{9}$ We formulate firms' pricing strategies as a single contract offered to all students to conform with the pricing practices we observe in our empirical context. There firms do not rely on mixed bundling, metering, or other types of menu pricing to induce self-selection by students. One possible reason for schools' reluctance to offer multiple contracts may be that offering a contract that explicitly conditions on the contingent fail event might increase consumer attention to the add-on price. A second concern for firms might be the risk that more explicit price discrimination may invite more stringent regulatory oversight.

${ }^{10}$ In their case of bank overdraft services, these translate into being unaware of the existence of or the exact
} 
In contrast, sophisticated students recognize the possibility of having to retake the exam. We assume they form rational expectations over their probability of failing the exam, assessing it correctly at $\lambda$, and consider the add-on service when making their school choice in the first period. Sophisticated students can engage in costly effort to reduce their probability of failing from $\bar{\lambda}$ to $\underline{\lambda}>0$ at an effort cost $e \underbrace{11}$

In line with our empirical setting, we follow Gabaix and Laibson (2006) in assuming that students make a discrete school choice, allowing for heterogeneous valuations of each school. We assume that there are no systematic differences in valuations by type. The utility of student $i$ of type $\{m, s\}$ from enrolling at school $j$ is given by

$$
\begin{aligned}
& u_{i j}^{m}=v-p_{j}^{u}+\varepsilon_{i j} \\
& u_{i j}^{s}=v-p_{j}^{u}-\lambda p_{j}^{a}+\varepsilon_{i j},
\end{aligned}
$$

where $\varepsilon_{i j}$ denotes student $i$ 's heterogeneous valuation for the school $j$, such as the distance he travels to the school, and $\lambda=\{\underline{\lambda}, \bar{\lambda}\}$, depending on whether the sophisticated student chooses to engage in effort. Note that we do not model the school's choice of whether to unshroud or publicize the upfront prices. We show in the Appendix that, in our setting where add-ons are unavoidable, the shrouded and unshrouded equilibria are equivalent if sophisticated students form rational expectations about add-on prices and unshrouding is costless. We therefore simply assume that sophisticated students are aware of the add-on price and form expectations solely with regard to their demand for the add-on, but not the firms' prices.

Individual demand for each school's services is given by the probability that the expected utility of school $j$ exceeds that of all competing schools $k \neq j$. Under the assumption that $\varepsilon$ is distributed type I extreme value, this assumption results in common multinomial logit school choice probabilities:

$$
\begin{aligned}
D_{j}^{m} & =\left[1+(n-1) \exp \left\{\frac{p_{j}^{u}-p_{-j}^{u}}{\sigma}\right\}\right]^{-1} \\
D_{j}^{s} & =\left[1+(n-1) \exp \left\{\frac{p_{j}^{u}-p_{-j}^{u}+\lambda\left(p_{j}^{a}-p_{-j}^{u}\right)}{\sigma}\right\}\right]^{-1},
\end{aligned}
$$

amount of the charges (possibly due to low salience of information), underestimating their amount or the likelihood of overdrawing the account, being aware of the charges but not anticipating having to pay them, or imperfectly tracking account balances.

${ }^{11}$ For example, they might study more for the theory exam or try harder at their on-road lessons so as to minimize their probability of failing and the likelihood they will be required to purchase the add-on service. 
denoting as $\sigma$ the scale parameter of the type I extreme value distribution.

Consider first the pricing in the add-on market. Since students are locked in to their school upon failing the initial exam, the school acts as a monopolist over its demand and optimally charges the highest possible price, $\bar{p}^{a}$.

Now consider pricing of the base service. In the Appendix we show that there is a unique symmetric equilibrium characterized by the following pricing strategies:

$$
\begin{aligned}
& \left(p_{j}^{a}\right)^{*}=\bar{p}^{a} \\
& \left(p_{j}^{u}\right)^{*}=c^{u}+\frac{\sigma n}{n-1}-[(1-\pi) \bar{\lambda}+\pi \underline{\lambda}]\left(\bar{p}^{a}-c^{a}\right),
\end{aligned}
$$

provided effort costs $e$ are at most equal to $(\bar{\lambda}-\underline{\lambda}) \bar{p}^{a}$.

In equilibrium, firms follow a loss-leader pricing strategy in which the upfront service is sold below competitive profit margins and the add-on service is priced at monopoly levels.

The equilibrium pricing strategies reflect that, while the add-on price is invariant to, the upfront service's price is increasing in the fraction of sophisticated types, or

$$
\frac{\partial\left(p_{j}^{u}\right)^{*}}{\partial \pi}=(\bar{\lambda}-\underline{\lambda})\left(\bar{p}^{a}-c^{a}\right) \geq 0
$$

Alternatively, as the size of the inattentive segment increases, the upfront price decreases to reflect that schools anticipate larger profits from the add-on service; schools want to attract more inattentive types upfront and recoup these losses in the add-on market ${ }^{12}$

The equilibrium pricing strategies in (3) together with these observations yield the following testable predictions:

Prediction P1. Prices in the upfront market decline as the number of firms increases. With large $n$ and a sizable add-on market, the model allows for the possibility that margins in the upfront market are negative and are offset by large, positive markups in the add-on market.

Prediction P2. The price of the upfront service is monotonically decreasing in student types' average probability of failing the exam, $[(1-\pi) \bar{\lambda}+\pi \underline{\lambda}]$. The greater the number of students schools can attract in the add-on market, the lower the price they charge in the upfront market to entice students to sign up with them.

\footnotetext{
${ }^{12}$ This conclusion depends on the relative ordering of the probabilities of failing by inattentive and sophisticated types. If sophisticated students had a strictly higher probability of failing than inattentive ones, regardless of their expended effort, the price of the upfront service would increase in the inattentive segment share.
} 
Prediction P3. Prices for add-on services do not decline as the number of firms in the market increases.

Prediction P4. The add-on price does not depend on students' probability of failing.

Prediction P5. Sophisticated students engage in costly effort to reduce their exposure to the add-on market. Such effort reduces their probability of failing from $\bar{\lambda}$ to $\underline{\lambda}$ (i.e., to a level below that of an inattentive student).

In Sections 4 and 5 we assess the plausibility of some of the model assumptions and test Predictions P1-P5 using the market for driving instruction. We first describe the market for driving instruction in Portugal and summarize our sources of data.

\section{$3 \quad$ Background and Data}

\subsection{The Portuguese Market for Driving Instruction}

We begin with an overview of the process of obtaining a driver's license in Portugal, the market for driving instruction, and the role of the IMT as the regulatory agency that oversees driving instruction.

To obtain a driver's license, any individual aged 18 years or older must first enroll in an IMTauthorized driving school ${ }^{13}$ There, candidates must complete 28 theory lessons, the curriculum of which is set by the IMT, and a minimum of 32 on-road driving lessons; students cannot legally practice driving without the presence of an instructor and outside of a lesson paid to a driving school. After completing the required theory lessons, students take a computerized theory exam. Subsequently, they perform an on-road driving test. Firms typically charge a single fee for the base course of instruction, covering classroom time, materials, practice theory exams, on-road driving lessons, and the exam administration by the exam center.

If a candidate fails either the theory or the on-road exam, he must pay the school a fee to retake the exam and, in the case of the on-road portion, to complete five additional driving lessons. Both exams are administered at one of 35 exam centers, and the IMT charges schools an exam fee for each student that the school signs up for the exam. The student does not pay the exam center directly for any exam administration; the fact that the school does, but does not need to inform

\footnotetext{
${ }^{13}$ Licensing by the IMT requires, among other things, proof that the proposed school owner holds at least five years of experience in driving instruction, that the school is financially viable, and that the fleet and facilities satisfy certain IMT standards.
} 
the student of the magnitude of the exam registration fee it pays to the center, is one reason why schools are able to mark up the price of repeat courses. Twenty-two exam centers are managed by the IMT, while private organizations operate the remainder. The computerized theory exams that are administered at both public and private centers are based on IMT-proprietary software that ensures exams are controlled tightly. An IMT certified examiner oversees the on-road driving test.

As of 2010, there were 1,141 driving schools in mainland Portugal. Since 1998, the industry has more than doubled in terms of number of firms. Entry resulted from significant liberalization efforts that lifted restrictions tying the maximum number of schools serving each municipality to population: each licensed school had to serve a minimum of 25,000 residents or be the sole provider in a municipality with less than 25,000 residents.14 We exploit the previously regulated market structure as an instrument for the current market structure in some of the empirical analyses below.

A number of regulatory restraints remain in place, including territorial restrictions limiting all business to be conducted within the municipality covered by the owner's school license, and regulations governing the sharing of resources between commonly-owned schools that limit the presence of multi-outlet chains of schools. Eighty-seven percent of owners operate a single school, and another nine percent operate two schools. Panel (a) in Figure 1 plots the locations of all driving schools in mainland Portugal by municipality population density.

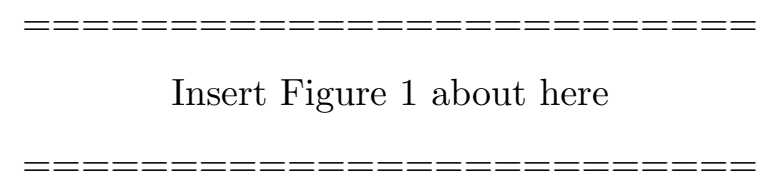

\subsection{Data}

Our empirical analysis combines a number of data sets at the school, student, and municipality level. First, from the IMT, we obtained data on school characteristics related to its instructors and driving fleet. These data originate from the school's licensing application and are updated periodically. We geocoded school addresses using GIS software and added hand-collected school prices and estimated costs. Second, the IMT provided individual-level school enrollment and driving exam information for the universe of students who obtained their driver license in 2009 or 2010 and

\footnotetext{
${ }^{14}$ Prior to liberalization this same formulaic determination of the maximum number of firms, based on the population of each market, was applied nationwide. There is no evidence of exceptions that made it possible that, for example, a higher number of schools than the one allowed by law operate in more profitable markets.
} 
enrolled in a school as early as January 1, 2008. Finally, we obtained demographic and other data at the level of the parish or municipality from the market research company Grupo Marktest, the Ministério do Trabalho e da Solidariedade Social, and Statistics Portugal.

We focus on applicants for a category-B passenger-vehicle license (the most common type of driver's license which excludes trucks and other specialty vehicles), resulting in a loss of 16.3 percent of candidates. Further, we restrict the sample to candidates for whom we have a complete history profile from enrollment at a school to completion of the on-road exam, which eliminates 2.1 percent of category-B students who took the theory exam prior to 2008 (we only have access to theory exam data from 2008 onwards).

Our empirical analysis treats a municipality as the relevant market area within which firms compete and students choose schools. In line with this assumption, we exclude the districts of Lisbon and Porto from the sample. While schools are required to conduct their business within the municipality covered by their license, students can attend a school outside of their municipality of residence. Since Lisbon and Porto are large, densely populated districts, the assumption of a single municipality comprising the relevant market area is less reasonable there. Eliminating students residing in Lisbon or Porto reduces the number of category-B applicants by 35 percent. We further restrict our sample to schools to municipalities where complete price information is available for all schools, as discussed below.

The final sample contains 90,446 students residing in one of 214 municipalities with a total of 636 schools. These are displayed in panel (b) of Figure 1.

\subsubsection{Sample Markets}

Table 1 describes the characteristics of the sample of markets. The average (median) municipality contains 3.2 (2) driving schools, ranging from 1 to 22 schools. Such a wide range facilitates assessing how prices change when we move from a monopoly to a perfectly competitive environment. Municipalities range in population from 2,952 to 181,474 residents, with an average population of 27,158 people living in one of 24.8 parishes; on average, there are 422.6 driving school students during our data period in a given municipality. Eighty percent of residents live in a parish that is

either moderately or predominantly urban. Monthly wages amount to $€ 861.25$. Thirteen percent of residents have completed some level of post-secondary education. The average monthly rent of $€ 137.10$, the availability of commercial properties proxied by the share of non-residential buildings of 8.9 percent on average, and the number of auto repair shops of 62 on average serve as shifters of 
the schools' costs.

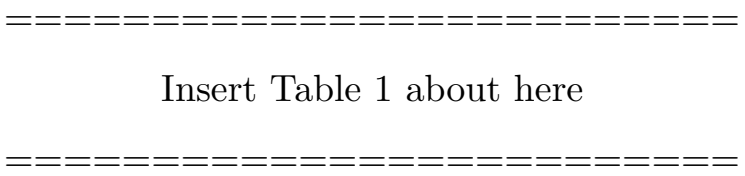

\subsubsection{School Characteristics}

Here, we summarize school characteristics, the size of the schools' student body, and market shares. See Table 2, For the average school, 142.2 students began and completed their course during our sample period $\sqrt{15}$ There is significant variation in enrollment figures across schools, however; the interquartile range of enrollment spans from 87 to 176 students.

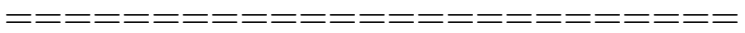

Insert Table 2 about here

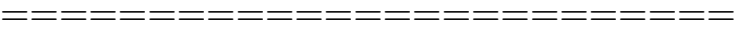

The average school employs 5.8 instructors who have worked in the firm for eight years. The median school has a driving fleet consisting of three passenger vehicles, for which we observe characteristics such as displacement, age, and weight. We calculate the straight-line distance from the school to the nearest district-wide IMT office and to its most frequently used exam center to proxy for costs of interacting with the IMT and of transporting students to the exam center. The average school is 23.4 kilometers from the closest IMT office and 21.1 kilometers from its most commonly used exam center.

The IMT does not collect price information. We complement the IMT data with hand-collected, detailed prices. We employed a team of 14 mystery shoppers who visited each school in person between November 2011 and March 2012 with an identical script to obtain information on base prices and repeat fees.16

The bottom panel of Table 2 summarizes the distribution of prices across schools and markets. The median school charges $€ 700$ for its base driving course, with an interquartile range of $€ 150$.

\footnotetext{
${ }^{15}$ Note that the student body of the typical school is significantly larger due to the fact that we restrict the sample to students who began and completed their course in our sample period. In total, over the three year period, the average school enrolled 425.9 students.

${ }^{16}$ Out of the 245 municipalities outside of the Lisbon and Porto districts, we drop 31 municipalities due to incomplete price information for at least one school in the municipality.
} 
Thus, there is significant variation in prices, likely due to cost and demand differences across municipalities. Accordingly, the between-municipality standard deviation is 2.2 times the withinmunicipality standard deviation in upfront prices. The average on-road repeat course fee of $€ 275.2$ is more than double that of the theory repeat course fee, $€ 129.1$, mostly due to the on-road repeat course including five additional driving lessons.

\subsubsection{Marginal Costs}

To assess the profitability of each of the services, we estimate schools' marginal costs. We also use the marginal costs estimates to rule out alternative explanations for the results found in Section 4.3 (see Section 6). We benefit from the simplicity of the service offered and exploit information contained in a template that the industry association Associação Nacional dos Industriais do Ensino da Condução Automóvel (ANIECA) provides to members to estimate annual operating costs, including both total and unit costs.

According to the cost template, the base course marginal cost per student consists of: (i) fees paid to the exam center for one theory and one on-road test administration; (ii) the cost of instructional materials for the theory lessons; (iii) the instructor salary for 32 driving lessons and for the final on-road driving exam (which the instructor needs to attend); and (iv) the vehicle operating costs of driving one of the school's vehicles during the practice lessons and the exam (cost of gasoline, depreciation expenses, maintenance and repairs, tolls and other road fees and taxes, and other expenses). The school's cost of the theory repeat course is limited to the student's theory exam fee, which is identical to the fee it pays to the exam center the first time the student takes the exam. For the on-road repeat course, the school incurs exam administration fees, as well as labor and vehicle maintenance costs equivalent to five driving lessons plus driving to the exam.

We use information on exam center fees, municipality-level salaries, local gasoline prices, the estimated distance in kilometers covered during a 32-lesson and a five-lesson course of instruction, and the annual usage in kilometers of each school's fleet of cars to derive marginal cost estimates (see Appendix B for details). Per student, we estimate that the average school pays $€ 53.02$ in exam fees to cover the cost of one theory and one on-road exam (see Table B.1). The cost of instructional materials is minimal and standardized, amounting to $€ 10$ per student. We estimate that instructor wages amount to $€ 235.6$ and $€ 42.8$ for 32 and five on-road lessons at the average school, respectively, capturing cost-of-living differences reflected in municipality-level incomes across municipalities. Vehicle operating costs represent the largest source of marginal costs; we estimate the costs of 
gasoline, depreciation, and maintenance and repairs to amount to $€ 0.28$ per kilometer 17 When scaled by the 722.9 kilometers the average student covers during the driving course and exam itself, the vehicle operating cost for the base and on-road repeat courses amount to $€ 203.7$ and $€ 34.3$ on average.

In total, the average school incurs an estimated marginal cost of $€ 502.9$ per student in the base course, with a standard deviation of $€ 40.8$. The add-on services generate estimated marginal costs of $€ 16.4$ and $€ 113.8$ for the theory and on-road repeat courses, respectively. We verified the reliability of our cost estimates in interviews with driving school owners and using feasibility studies that potential entrants prepare for the IMT as part of the licensing process. Our cost estimates are comparable to the new entrants' own cost estimates for a country-wide sample of schools.

\subsubsection{Student Attributes}

The IMT student records contain the date on which the student obtained his learner's permit and the category of the permit, the dates, times, exam centers and outcomes of each exam, the issue date of the license, as well as the candidate's age, gender, and the seven-digit postal code of his residence, which approximately designates a city block.

Table 3 shows that the average (median) student in our sample is 21.9 years (19.1 years) old. There is an even split of male and female students: 51.6 percent of our sample is female.

We assume that each student lives at the centroid of his postal code area to compute the straight-line distance to his chosen school. Not only are a majority of students located less than three kilometers from their schools (median distance of 2.9 kilometers), but 46.4 percent of students choose the school closest to home. Clearly, spatial differentiation is an important dimension of pricing.

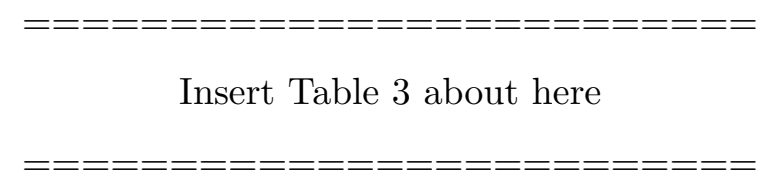

\footnotetext{
${ }^{17}$ This compares to estimates of vehicle operating and ownership costs provided by the Automóvel Club de Portugal ACP.
} 


\section{Pricing in the Upfront and Add-on Markets}

In this section, we investigate the extent to which prices conform to Predictions P1-P4 of the theoretical model presented in Section 2 (we test the remaining Prediction P5 in the next section), establish the plausibility of the model assumptions, and describe the economic relevance of the retake markets more generally. We begin by summarizing students' exam outcomes, school pass rates, and thus the size of the repeat market.

\subsection{Incidence of Exam Repetitions}

Figure 2 and Table 3 suggest that the add-on market is sizable. Only 76.0 and 73.2 percent of students pass the theory and on-road exams on the first attempt, respectively. The two exams' outcomes are largely independent since only 55.8 percent pass both exams on the first attempt. The average student takes the theory and on-road exams approximately 1.37 and 1.36 times, respectively. This results in the driving school process being lengthy; the median student takes seven months from start to finish.

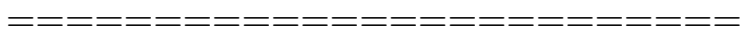

Insert Figure 2 about here

The data also provide evidence to support our model assumption that students are de-facto locked into the school by their initial choice and rarely switch schools. Only 1.8 and 0.1 percent of all students transfer schools during the theory and on-road exam phases, respectively, while only 0.7 percent transfer in between the theory and on-road exam phases. The majority of these, or 64.5 percent, transfer to schools outside their original school's municipality, suggesting that exogenous reasons such as moving explain a significant share of transfers. The primary switching cost is that, by regulation, lessons taken at one school do not transfer to another school; switching schools requires restarting the base course from the beginning. This is costly: given each student's current school choice, the cheapest base course of instruction at a different school in the municipality has a price equal to 5.4 times the current school's theory repeat fee and 2.4 times its on-road repeat fee, on average 18

\footnotetext{
${ }^{18}$ Given the low empirical incidence of school switching, we ignore the possibility of inducing it through primary good pricing. See Miao (2010) for a theoretical analysis of such simultaneous add-on and primary good competition.
} 
The theoretical model also suggests that schools' add-on prices would be set at their market's "walkway" price, or the maximum supportable price in the market. The data provide evidence that this assumption is reasonable. First, conditional on failing at least one exam, students are more likely to quit than to transfer. While in total, 0.9 percent of students switch schools within the same municipality, more than double - or 2.6 percent of students - quit (not tabulated) ${ }^{19}$ Second, conditional on failing at least one exam, students who quit also behave in ways we would expect. Unreported conditional logit regressions of the decision to quit show that students are more likely to quit schools with higher repeat fees for the particular exam that they failed, a statistically and economically significant finding that is robust to adding school- and municipality-level controls. Note that if price is correlated with other components of school quality not captured by our controls, this estimated price effect would be downward biased.

\subsection{Markups}

To assess the profitability of offering the three services (that is, the base course and each of the two repeat exams), we consider estimated price-cost margins and the percentage markup (ratio of markup to price). Table 4 summarizes both. In addition, Figure 3 shows the distribution of the percentage markups.

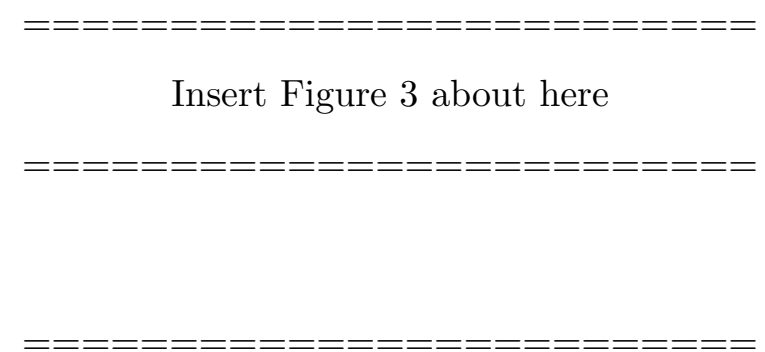

Insert Table 4 about here

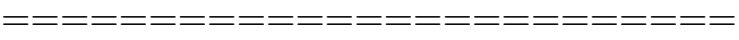

Based on our estimated marginal costs, the average percentage markup for the upfront service is 27.2 percent, while in contrast, the percentage markups in the add-on markets is significantly higher, averaging 86.4 percent and 57.5 percent in the theory and on-road add-on markets, respectively. The fact that markups are higher in the repeat than in the base markets is corroborated by the fact

\footnotetext{
${ }^{19}$ Quitters are defined as those students for whom more than a year passes between successive exams, conditional on failing the last exam taken, or as those students who fail their last observed exam prior to Dec 31 , 2009 and disappear altogether after that last instance.
} 
that, in total, repeat fees amount to 58.5 percent of base prices for the average school, despite the fact that the theory retake requires no and the on-road retake requires only five (or 17.9 percent of the base course's requirement) additional lessons.

Thirteen schools, or 2.0 percent of the sample, have negative markups in the upfront market, pricing below estimated cost. All but two of these schools earn positive total profit from the three services, however ${ }^{20}$ Schools are able to cover their total variable costs with the revenues they earn from the add-on markets despite the losses they incur in the upfront market. We compute effective markups as the total fees paid by each student less the total variable cost incurred in serving the student, averaging across students at each school. A school earns $€ 313.8$, or 33.8 percent of fees paid, on the average student.

Together the markups and exam repeat incidences imply that a significant portion of schools' variable profits derive from add-on fees, consistent with the properties of the loss-leader equilibrium described in Section 2, The median school derives 32.6 percent of profit overall from repeats broken down into 10.5 and 22.1 percent from the theory and on-road exam add-on services, respectively. At the same time, schools earn a smaller share of total revenues from add-on services: the median derives 6.2 and 10.6 percent of revenue from the two add-on services for a total of 16.8 percent of revenue. Thus, more revenue is passed on as variable profits to schools in the add-on market.

\subsection{Determinants of Prices}

The previous section establishes that schools have a profit motive in the add-on market in which significantly higher markups are earned relative to the base course. We now explore whether the observed prices for the upfront and retake services are consistent with the predictions of the model from Section 2. We test whether prices for the base course of instruction, but not repeat fees, vary with the number of competitors in the market (Predictions P1 and P3), and with the students' probability of failing the exams (Predictions $\mathrm{P} 2$ and $\mathrm{P} 4$ ).

Figure 4 first summarizes the raw price patterns in the data showing a box plot of mean municipality upfront and repeat fees by number of competitors in the municipality. The plot is supportive of Predictions $\mathrm{P} 1$ and $\mathrm{P} 3$. upfront prices appear to decline in the number of competitors, while add-on prices do not. Empirically, there is also only a weak correlation of the base course and the theory repeat course prices (0.071), or the base course and the on-road repeat course prices

\footnotetext{
${ }^{20}$ We estimate that the two school outliers have negative markups per student of $-€ 21.0$ on average across the three services. We are unable to determine whether this is because of measurement error in cost or recorded prices or because these schools truly incur a loss.
} 
(0.083), but a stronger correlation between the two add-on prices (0.352). Both of these sets of correlations provide initial evidence that factors affecting the setting of schools' upfront prices differ from those affecting their add-on prices.

Since Figure 4 does not control for other potentially confounding school and municipality characteristics, we test the above predictions more formally in regression models of prices on market structure and the students' probability of failing, controlling for heterogeneity in demand and cost conditions across schools and municipalities. We employ both OLS and instrumental variables techniques to control for the possibility that the number of competitors is endogenous to school prices; for example, both entry and prices might be higher in markets with unobservably high demand, biasing the estimated coefficient on market structure upward.

We control for such potential endogeneity by employing the regulated number of schools per municipality prior to liberalization as an instrument: by being tied to population, it is likely uncorrelated with unobserved profit shifters that are reflected in prices in the current regime, but is related to the number of schools in the municipality under free entry. As additional instruments, we employ fixed cost shifters of the school, including its distance to the local IMT office, capturing the cost of doing business with the IMT, as well as the proportion of nonresidential buildings and the average rent in the municipality to capture office rental costs.

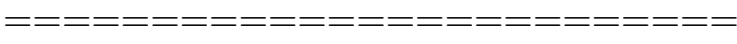

Insert Figure 4 about here

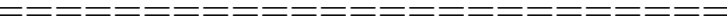

The results of the regressions of the upfront prices on the number of market competitors with school- and municipality-level controls are shown in Table 5 . The first-stage $F$-statistics and partial $R$-squared statistics for the instrumental variables regressions imply strong instruments at conventional levels, and the 2SLS results in column (3) enhance the negative effect of competition, relative to the OLS results, as expected. For every school added to the market, the upfront price decreases by approximately $€ 10.87$ (€9.52 under the OLS specification), corresponding to two percent of the average upfront price.

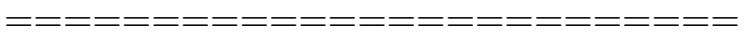

Insert Table 5 about here

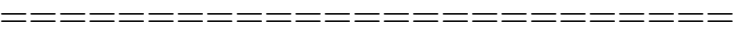


Relaxing the linearity assumption of competition on price underlying specification (1) by including market structure dummies for each observed firm configuration suggests that the decline in prices is more pronounced in going from monopoly to duopoly markets, when prices drop by $€ 28.2$ in the OLS specification (see column (2)). The largest markets with six or more competitors have prices that are on average $€ 85.1$ lower than monopoly markets. To address endogeneity concerns in the nonlinear specification, we account for the fact that the endogenous variables are discrete market structure outcomes by modeling them as an ordered probit model, allowing entry to shift with municipality characteristics that are shared by the price model as well as the excluded instruments. To capture the source of endogeneity concerns, we introduce an unobserved market-level error in the price equation that is correlated with the error that drives aggregate entry decisions. We estimate the resulting two-equation model using full information maximum likelihood (FIML) and derive the likelihood in Appendix C. The results for this specification are reported in column (4). While not directly comparable to the OLS results (which did not include a market-level random effect in the pricing equation), the estimated price effects are similar to the 2SLS results. These results are consistent with Prediction $\mathrm{P} 1$ that prices in the upfront market decline as the number of firms increases.

Across specifications, prices also respond to the share of students who fail both exams, our proxy for the add-on market size, as suggested by Prediction $\mathrm{P2}$. A one standard deviation increase in the share of students who fail both exams (3.9 percent) is associated with a decline in price of between $€ 6.56$ to $€ 10.04$ across models. While this is consistent with the model prediction of shifting profit from the upfront to the add-on market, the effect is less pronounced than the effect of competition.

Table 6 shows the results for the equivalent regressions of add-on prices on the number of market competitors and the size of the add-on market. We collapse repeat fees into a single sum of the two, which we employ as our dependent variable. As with the upfront price regressions, the results are robust to instrumenting for the number of firms and introducing school- and municipality-level controls. For all models, the number of schools in the municipality is statistically insignificant in affecting the repeat fee. The results, thus, suggest that even in competitive local markets, where prices for the base course of instruction are significantly lower than in more concentrated ones, firms are able to maintain high prices for add-ons ${ }^{21}$

\footnotetext{
${ }^{21}$ Earlier work on assessing the competitiveness of local markets as a function of the number of competitors Bresnahan and Reiss 1991, Asplund and Sandin 1999) finds for professional services settings, including the specific case of driving schools, that by the time four or more competitors operate in the market, market conduct approaches competitive levels, as evidenced by the finding that the number of customers required to support an additional firm in the market does not change with the number of firms, and hence margins are approximately constant.
} 
Similarly, the size of the add-on market - the share of students failing both exams - does not have a significant association with repeat fees. These results lend support to Predictions $\mathrm{P} 3$ and $\mathrm{P} 4$. They also suggest that the share of failing students does not simply proxy for school quality, which would be an alternative explanation for why prices for the base course might be lower for schools with higher fail rates. If firms were simply differentiating on quality in their pricing, we would expect better schools (with lower pass rates) to charge higher prices for both the upfront course and the repeat course, which we do not find to be the case. We also employ a rich set of school characteristics, such as the age of the instruction vehicles or the experience of the instructors, to control for the role that vertical differentiation might play in pricing. In an unreported robustness check, we re-estimate specification (3) in Tables 5 and 6 , now also instrumenting for the share of failing students with exogenous characteristics (the average age, female share, and share with higher education) of a school's potential customers, which we define to be all students residing within a $10 \mathrm{~km}$ radius of each school. With the exception of reinforcing the negative effect of the share of failing students on the base price, doing so does not qualitatively change the results.

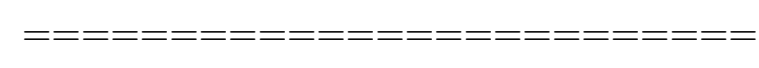

Insert Table 6 about here

\section{Survey Evidence}

The evidence presented so far supports the model's predictions related to firms' pricing strategies in the upfront and add-on markets. Since the administrative data do not contain direct information on students' expectations of the cost or incidence of exam failures, nor information on students' effort, we develop and conduct a survey, jointly with the IMT, to investigate the extent to which students are aware of the prices of the add-ons they may have to pay later on and their expectations of use of the repeat course, or add-on demand, relative to their actual usage incidence. To the extent that inattention drives schools' abilities to charge high markups for repeat fees even in competitive municipalities, the goal of the survey is to disentangle sources of such inattention of contingent add-on fees, either in affecting perceptions of the likelihood of failing or the repeat fee. The survey also investigates whether sophisticated students engage in more effort than inattentive students, possibly to reduce their exposure to the add-on market (see Prediction $\mathrm{P5}$ above). 
The IMT administered the survey at the public exam center in the Setúbal district. The particular exam center is large, covering a significant share of students, schools, and market structures, and is representative in terms of school characteristics: Of our sample, the exam center administered $4.09 \%$ of all exams, ranking 9th out of 29 exam centers, and served 12 municipalities, with between 1 and 14 schools, for a total of 41 out of 636 schools. The schools charged on average $€ 699$ for the base course, and $€ 110$ and $€ 270$ for the theory and on-road repeat courses, respectively.

The survey was offered to all students who took the theory driving exam during the months of December 2012 and January 2013, immediately after having taken the exam, and prior to learning the exam outcomes. Participation in the survey was voluntary; the examiner presented it to students as being part of a general study on driver education and testing. Figure 5 depicts the survey. The IMT shared the anonymized compiled survey responses with us, together with information on the students' ultimate performance on the theory exam and the later on-road exam. The survey is thus unique in allowing us to look at ex-ante expectations of failing, rather than stated expectations after the exam outcome is known, and in linking those ex-ante expectations to ex-post behavior.

In total, 797 students took the theory exam in Setúbal during the two-months window of the survey, and 782 students participated in the survey, entailing a 98 percent response rate. In the following analyses, we focus on first-time theory exam takers of the passenger vehicle (category B) license exam only, resulting in a sample of 440 respondents. The resulting sample is representative of the main sample: 51.8 percent are female; the mean (median) age at the time of the theory exam is 22.6 (19.7) years with a standard deviation of 7.1 years.

To investigate the extent to which students are unaware of add-on prices, we asked the students whether they would have to pay an additional fee to retake the theory exam in case they failed the exam they just took (see Question 4 in Figure 57. Table 7 summarizes the responses to this question. Among respondents, 4.1 percent stated they would not have to pay anything; 17.5 percent did not know; and 78.4 percent said that they would have to pay some amount. Of these students, 26.4 percent state that they asked the school whether they would have to pay, and 43.3 percent state that the school informed them directly that additional fees would accrue. However, only 66.4 percent of the students who expect to pay for a retake, or 52.0 percent in aggregate, stated that they knew the amount they would have to pay. This share is higher among female students, 56.6 percent of whom state knowledge of the amount of retake fees. The students who answered that they know the retake fees are close to correct, underestimating the retake fees by only 4.1 percent on average (not tabulated). 


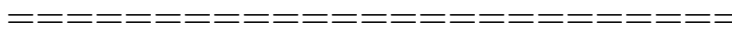

Insert Table 7 about here

$==================$

To simplify our subsequent analysis of the survey results, we classify students as "informed" or "uninformed" based on their responses to Question 4. Informed students are defined as those who report being aware of the existence of repeat fees (categories 3 and 4 in Table 7) and uninformed students are defined as those that are not aware of repeat fees. Note that the mapping between the definitions of informed/uninformed in the survey and sophisticated/inattentive in the model is not perfect. While uninformed students are also inattentive, a share of the informed students may in fact be inattentive; that is the case if some of the informed students are overly optimistic about their probability of passing the exam, which leads them to disregard the add-on prices. Thus, the nontrivial proportion of uninformed students in the survey of 22 percent is likely a lower bound on the share of inattentive students in the market.

According to the theoretical model, sophisticated students correctly assess their probability of failing while inattentive students disregard the add-on, possibly due to an underestimation of their probability of failing. We look for support of this assumption by testing whether students correctly anticipate their likelihood of failing an exam; a misassessment of the latter could, similar to lack of information about prices, induce them to put little to no weight on add-on prices at the time of school choice. To do so, we compare students' expectations of passing the on-road exam (Question 7 in the survey) with their actual outcomes. Note that, due to the timing of the survey, immediately following the theory exam, students have different amounts of information when answering this question and the identical question about passing the theory exam (Question 3 in the survey). For the average student in the sample, the on-road exam takes place three months after having answered the survey and on-road training has not yet begun. Their assessment of their likelihood of passing is thus not yet contaminated by first-hand experience of their ability, similar to their assessment of their likelihood of passing at the time of initially signing up for a driving course. In contrast, their assessment of passing the theory exam is based on having just taken the exam and thus reflects instead their ability to translate their experience with the exam into a passing score ${ }^{22}$

\footnotetext{
${ }^{22}$ Unfortunately the survey does not allow us to assess the students' expectations about their exam performance at the time of school enrollment, the experiment that would most closely line up with the theoretical model. Nevertheless, the above documented lack of correlation between theory and on-road exam performance suggests that already having taken the theory exam does not provide the student with significant additional information about their likely performance on the on-road exam.
} 
Thus, if overoptimism about exam performance were present, it is likely to be more salient for the on-road exam than for the theory exam.

Table 8 compares the expected and actual exam outcomes for different types (informed vs. uninformed and male vs. female) of respondents. Similar to the nationwide sample, among survey respondents failing a driving exam is common: only 72.5 percent pass the theory exam at first try, while 76.6 percent pass the subsequent on-road exam at first try. In aggregate, students have near correct expectations regarding the likelihood of passing the theory exam at 69.1 percent. The only demographic group for whom there is a statistically significant difference between the expected and the actual pass rate is female students, whose expectation falls short of the actual exam outcomes by eight percentage points. The lack of a statistically significant divergence between expected and actual outcomes in aggregate, among male students, and for the informed and uninformed subgroups, however, suggests that once the exam has been taken, the average student has an accurate understanding of how his performance compares to the passing standard.

At the same time, there is evidence of over-optimism in passing the future on-road exam: 86.6 percent of students state that they believe they will pass that exam, compared to the 76.6 percent who ultimately do. Similar differences between expectations and outcomes persist in subgroups, with male and uninformed students having the largest differences. On average, the uninformed (informed) students' expected pass rate exceeds their actual pass rate by 14.3 (8.9) percentage points. In the model, such uninformed students - but not all informed students - would be classified as inattentive. The fact that uninformed students overestimate their pass rates more than informed students thus provides support for the modeling assumption of sophisticated students placing more weight on repeat fees than inattentive students.

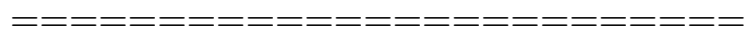

Insert Table 8 about here

Finally, we use the survey to gain insight into the students' preparation (as a measure of "effort") for the exam to test Prediction P5 that sophisticates are able to decrease their ex-ante probability of failing by engaging in effort. Because students may differ in what they consider to be significant effort, the survey asked them specific questions regarding the number of practice exams taken, use of the textbook, additional theory lessons taken, preparation of the lessons' material before class, 
note taking, and interactions with the instructor (see Question 5 in Figure 5 ) ${ }^{23}$ We developed this list after interviewing several driving school instructors, examiners, and students to understand what distinguishes well-prepared students. Since the students had not begun their preparation for the on-road exam yet, these questions focus on their preparation for the theory exam.

As Table 9 shows, the evidence is suggestive that sophisticated students engage in more effort in their exam preparation than inattentive students. For three out of the seven effort items in Question 5, the difference in effort between informed and uninformed students is significant and positive, and almost significant at the 10 percent level for a fourth item 24

Recalling from Table 7 that pass rates are higher for informed than for uninformed students (albeit with a one-sided p-value of 0.23 only in the case of the theory exam), there is some evidence that this higher effort translates into lower fail probabilities, consistent with Prediction P5 of sophisticated students engaging in effort that reduces their probability of failing and therefore their exposure to the add-on market.

\section{Alternative Explanations and Robustness}

Here we consider alternative explanations for the observed pricing patterns and robustness checks to the above results. The fact that markups on add-ons significantly exceed those on base product prices may be indicative of price discrimination, rather than inattention. This would be an optimal response for the schools if students who are more likely to fail one of the exams are also less price sensitive than others, that is if there is a correlation between the students' add-on demand and their price sensitivity.

To investigate this alternative explanation, we estimate exam outcome models in which the students' individual propensity to fail an exam is modeled as a function of student and school characteristics, as well as proxies for the students' price sensitivity. Table 10 reports the results. We include two measures of price sensitivity: first, we construct a measure of revealed price sensitivity that classifies students who choose a school that is not their closest, but charges the cheapest base course fee in the municipality. Second, we consider differences in the students' total cost of attending a school, including price and travel cost. A student with a higher total cost of school

\footnotetext{
${ }^{23}$ The block of questions in the questionnaire related to effort includes one - the last - question that is reverse keyed. This allowed us to check for response bias that could originate from respondents "straightlining" their answers in this block of questions. We could find evidence of "straightlining" behavior only for four respondents. Our results are robust to removing them from the survey sample.

${ }^{24}$ Because not all informed students are sophisticated, the differences in effort between informed and uninformed students are lower bounds for the differences in effort between sophisticated and inattentive students.
} 
attendance should be more price sensitive than a student with lower total cost. We thus investigate whether students who live farther from the school, and thus have a higher travel cost, have lower add-on demand, for example because they engage in higher effort at completing the base course of instruction successfully thereby reducing the total cost of school attendance. To avoid the element of school choice contaminating the distance measure, we focus on a subsample of students who reside in monopoly markets and thus did not have a school choice to make. This is not possible for the first price sensitivity proxy, which relies directly on comparing the student's school choice to other alternatives. Neither revealed price sensitivity nor distance to the school correlate significantly with the propensity of failing either exam. We thus find little evidence in support of markup differentials between base and add-on fees resulting from price discrimination strategies on the part of firms; the latter would also not necessarily yield the prediction that add-on prices are invariant to market structure, as we find above.

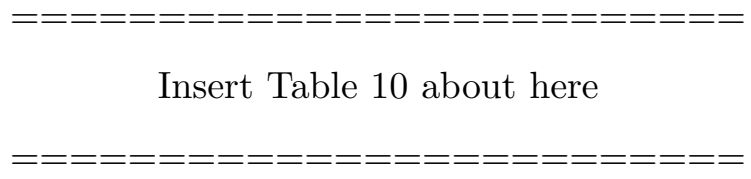

A second concern is that the model assumes that firms are symmetric in costs. If instead, firms differed in cost, such cost differences may be responsible for the patterns in prices uncovered in Section 4.3. For example, an alternative explanation for the observed decline in upfront prices as a function of the number of competitors could be that marginal costs are lower in markets with more competitors. While if that were the case, add-on prices should also decline in the number of competitors, we also investigate this and other possible explanations related to cost differences across schools by repeat the analyses in Tables 5 and 6 using markups as the dependent variables. The results in Appendix D, Tables D.1 and D.2, show economically similar and statistically stronger evidence that base markups, but not repeat course markups, decline in the number of competitors. These analyses also provide an additional robustness check for the estimated relationship between upfront and add-on prices and the share of exam repeaters that was found in Section 4.3 in support of Predictions $\mathrm{P} 2$ and $\mathrm{P} 4$. 


\section{Conclusion}

In this paper, we have presented a theoretical model in which firms take advantage of locked-in inattentive consumers by charging high fees in add-on markets. When consumers are inattentive to their demand for add-on products and services and face high switching costs, firms have the dual incentive to set as high a price as the add-on market can support and to charge a correspondingly low price in the upfront market to entice consumers to their firm in the first place. The model, hence, predicts that only upfront prices vary with the market structure a firm faces and depend on the distribution of consumer types in the market.

We present evidence of these phenomena in the context of Portuguese driving schools. We rely on detailed data of the driving school industry, together with student-level survey evidence. With data on prices and estimated marginal costs, we demonstrate that schools not only face a strong profit motive for setting high repeat fees, but also charge significantly higher markups in the add-on than in the upfront market, corroborating the model predictions. Survey evidence provides further support for the model's predictions in identifying a significant share of students as uninformed or over-optimistic, pointing to the possibility of schools' strategic exploitation of this subset of students.

Evidence that speaks to the extent of cross-subsidization, from consumers who are inattentive to those who are not, in a market such as ours is of significant normative policy interest to regulators. In the case of policies under consideration by the IMT, regulatory proposals range from requiring schools to inform students about typical propensities of failing exams to releasing price information

to directly or indirectly regulating prices in the add-on market. Policy makers' interest frequently stems from a concern that the inattentive consumer segment is more likely to be socially vulnerable. Investigating whether consumer inattention to add-on fees varies systematically with demographics is thus a valuable avenue for future research in informing public policy design. 


\section{References}

Alan, S., Cemalclar, M., Karlan, D. and Zinman, J. (2015). Unshrouding Effects on Demand for a Costly Add-on: Evidence from Bank Overdrafts in Turkey, NBER Working Papers 20956, National Bureau of Economic Research, Inc.

Armstrong, M. and Vickers, J. (2012). Consumer protection and contingent charges, Journal of Economic Literature 50(2): 477-493.

Asplund, M. and Sandin, R. (1999). The number of firms and production capacity in relation to market size, The Journal of Industrial Economics 47(1): 69-85.

Beggs, A. and Klemperer, P. (1992). Multi-period competition with switching costs, Econometrica 60(3): 651-66.

Bordalo, P., Gennaioli, N. and Shleifer, A. (2013). Salience and Consumer Choice, Journal of Political Economy 121(5): 803-843.

Bresnahan, T. F. and Reiss, P. C. (1991). Entry and competition in concentrated markets, Journal of Political Economy 99(5): 977-1009.

Brown, J., Hossain, T. and Morgan, J. (2010). Shrouded attributes and information suppression: Evidence from the field, The Quarterly Journal of Economics 125(2): 859-876.

Chetty, R., Looney, A. and Kroft, K. (2009). Salience and taxation: Theory and evidence, American Economic Review 99(4): 1145-77.

DellaVigna, S. and Malmendier, U. (2004). Contract Design and Self-Control: Theory and Evidence, The Quarterly Journal of Economics 119(2): 353-402.

DellaVigna, S. and Malmendier, U. (2006). Paying not to go to the gym, American Economic Review 96(3): 694-719.

Ellison, G. (2005). A model of add-on pricing, The Quarterly Journal of Economics 120(2): 585637.

Ellison, G. and Ellison, S. F. (2009). Search, obfuscation, and price elasticities on the internet, Econometrica 77(2): 427-452. 
Farrell, J. and Klemperer, P. (2007). Coordination and lock-in: Competition with switching costs and network effects, in M. Armstrong and R. H. Porter (eds), Handbook of Industrial Organization Vol. III, North-Holland, Amsterdam, pp. 1967-2072.

Gabaix, X. and Laibson, D. (2006). Shrouded attributes, consumer myopia, and information suppression in competitive markets, The Quarterly Journal of Economics 121(2): 505-540.

Grubb, M. D. (2009). Selling to overconfident consumers, American Economic Review 99(5): 17701807.

Heidhues, P. and Köszegi, B. (2010). Exploiting naïveté about self-control in the credit market, American Economic Review 100(5): 2279-2303.

Heidhues, P., Köszegi, B. and Murooka, T. (2016). Inferior products and profitable deception. Forthcoming in Review of Economic Studies.

Hossain, T. and Morgan, J. (2006). ...plus shipping and handling: Revenue (non) equivalence in field experiments on ebay, The B.E. Journal of Economic Analysis \& Policy 6(2): 3.

Jin, G. Z. and Leslie, P. (2003). The effect of information on product quality: Evidence from restaurant hygiene grade cards, The Quarterly Journal of Economics 118(2): 409-451.

Klemperer, P. (1987a). Markets with consumer switching costs, The Quarterly Journal of Economics 102(2): 375-94.

Kosfeld, M. and Schüwer, U. (2016). Add-on pricing in retail financial markets and the fallacies of consumer education. Forthcoming in Review of Finance.

Köszegi, B. and Rabin, M. (2006). A model of reference-dependent preferences, The Quarterly Journal of Economics 121(4): 1133-1165.

Miao, C.-H. (2010). Consumer myopia, standardization and aftermarket monopolization, European Economic Review 54(7): 931-946.

Oster, S. M. and Scott Morton, F. M. (2005). Behavioral biases meet the market: The case of magazine subscription prices, The B.E. Journal of Economic Analysis $\mathcal{E}$ Policy 5(1): 1.

Shulman, J. D. and Geng, X. (2013). Add-on pricing by asymmetric firms, Management Science 59(4): 899-917. 
Spiegler, R. (2006). The market for quacks, Review of Economic Studies 73(4): 1113-1131.

Spiegler, R. (2011). Bounded Rationality and Industrial Organization, Oxford University Press.

Stango, V. and Zinman, J. (2009). What Do Consumers Really Pay on Their Checking and Credit Card Accounts? Explicit, Implicit, and Avoidable Costs, American Economic Review 99(2): 424429.

Stango, V. and Zinman, J. (2014). Limited and varying consumer attention evidence from shocks to the salience of bank overdraft fees, Review of Financial Studies 27(4): 990-1030. 


\section{Figures and Tables}

Figure 1: Driving Schools by Municipality, Mainland Portugal

(a) All municipalities

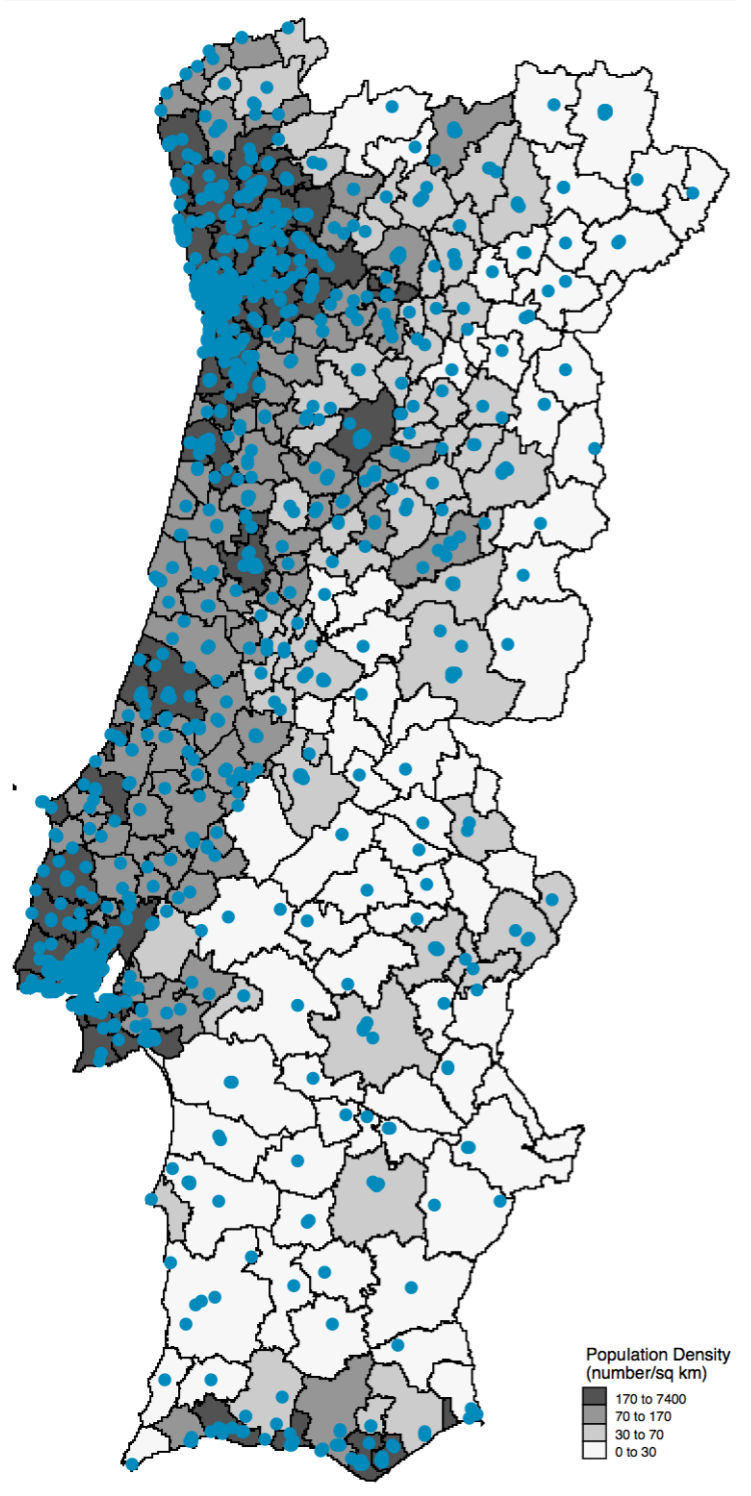

(b) Available sample of municipalities

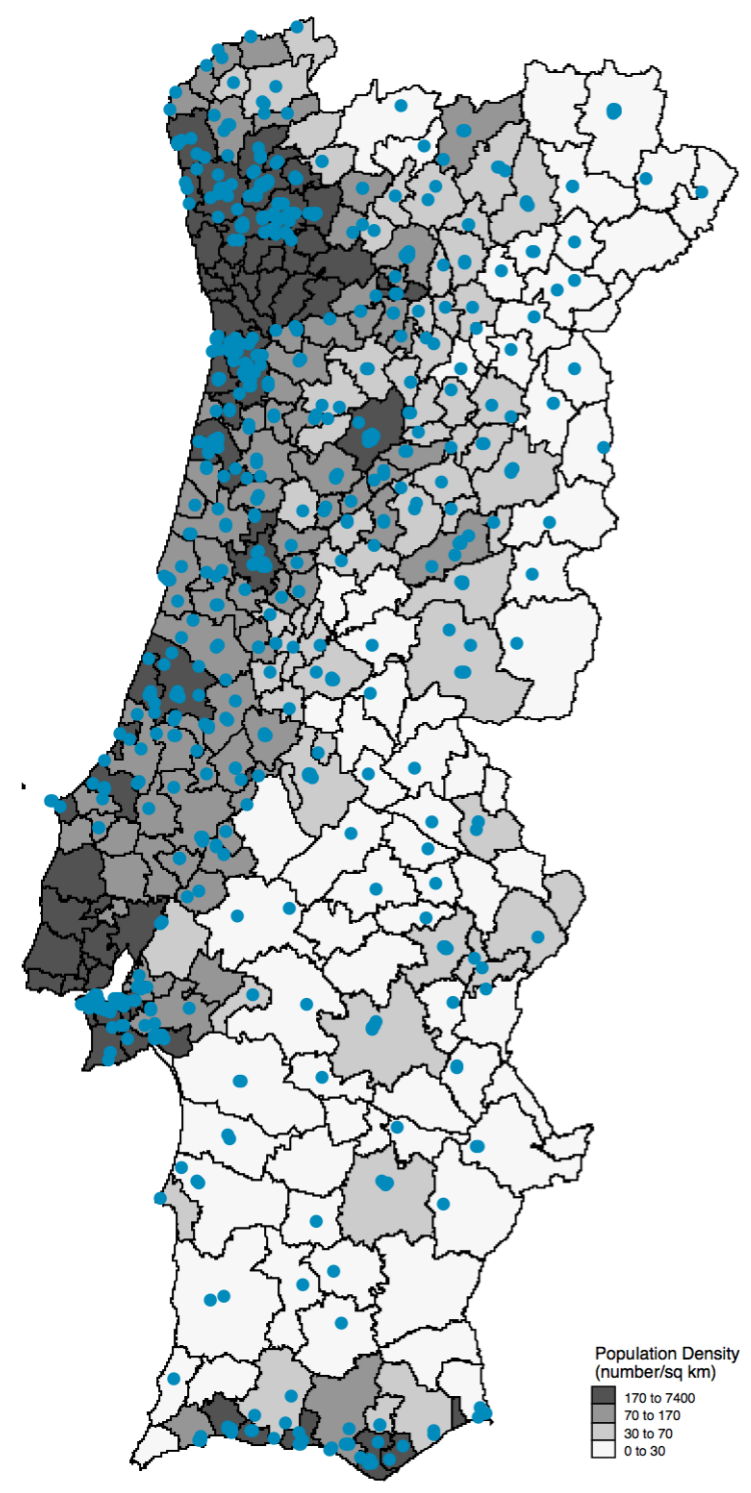


Figure 2: Number of On-road and Theory Exams Taken, by Student

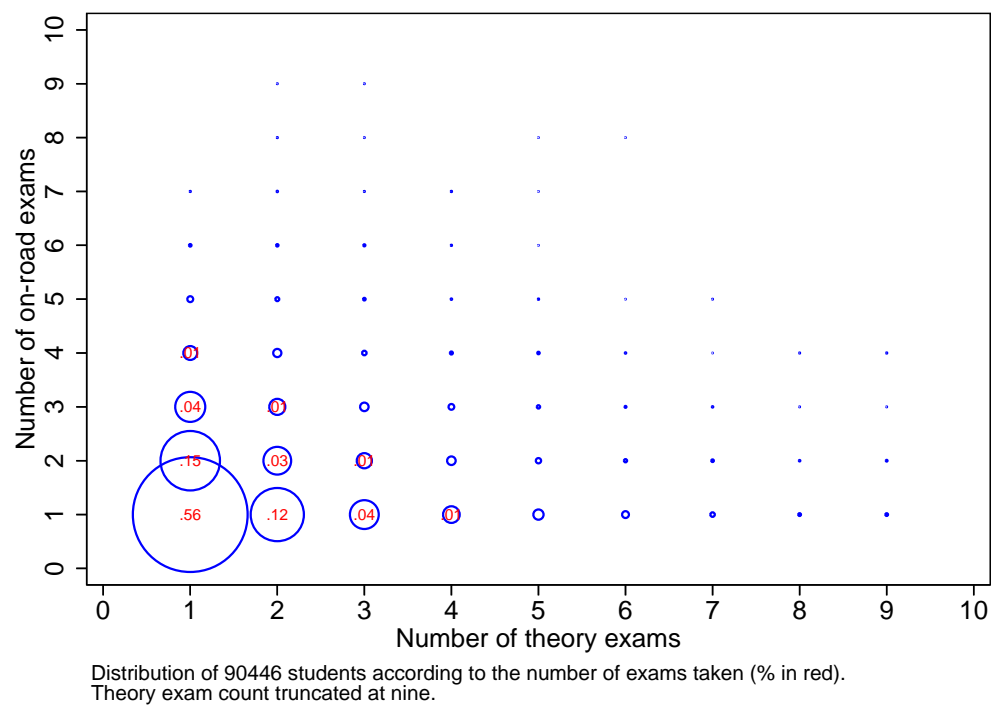

Figure 3: Distribution of Lerner Indices in Base and Repeat Course Markets, by School (\%)

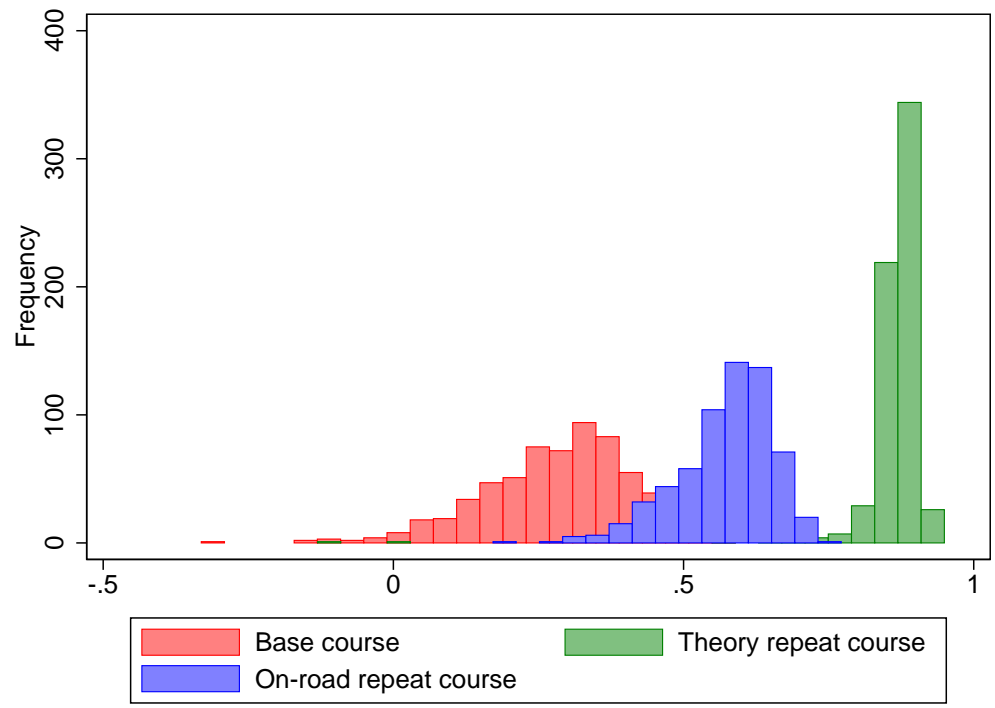


Figure 4: Average Municipality Prices by Number of Schools

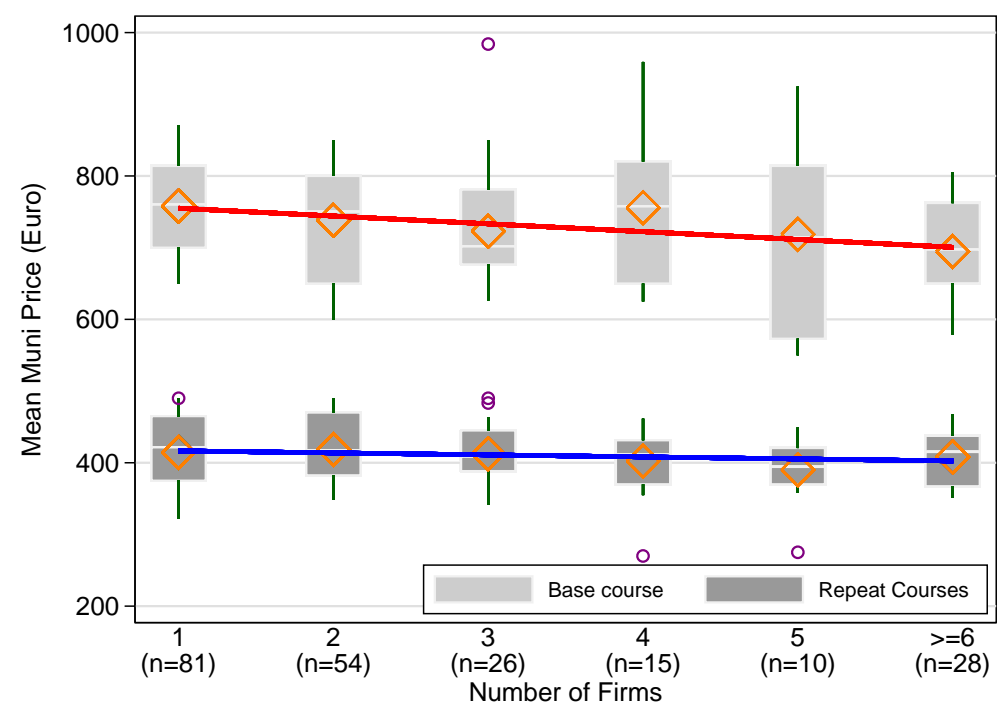

Note: Interquartile range of municipality prices conditional on number of schools. Diamonds indicate mean price level. 
Figure 5: Student Questionnaire

QUESTIONÁRIO QUESTIONNAIRE

No âmbito de um estudo sobre ensino e exames de condução agradecemos que preencha o

seguinte questionário. We are conducting a study concerning drivers' education and testing and would appreciate if you could answer the following questions

Preencha o que for necessário ou assinale com um $(X)$ a opção adequada Please fill in the blank spaces or mark your selection with an $\mathrm{X}$

1. Foi a primeira vez que fez exame teórico de condução?

$\square \operatorname{Sim} \quad \square$ Não

Was this the first time you took the theory exam?

Yes

2. O exame foi mais difícil do que esperava?

Was the exam harder than you were expecting it to be?

$\square \operatorname{Sim} \quad \square$ Não

3. Acha que vai passar no exame teórico que acabou de realizar?

$\square \operatorname{Sim} \square$ Não

Do you think you will pass the exam you just took?

4. Caso reprove, vai ter de pagar à sua escola de condução para repetir o exame teórico? In case you fail, will you have to pay your school to retake the theory exam?

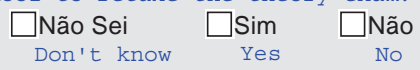

A) Aproximadamente quanto? (se não souber deixe em branco)

Euros

Approximately how much? (If you don't know please leave it blank)

Sei quanto é porque: $\square$ Perguntei na escola $\square$ A escola informou-me $\square$ Outro:

I know how much it I asked the school the school informed me other

is because:

B) Quanto acha que você devia ter de pagar para poder repetir o exame?

How much do you think you should have to pay to retake the exam?

Euros

5. Assinale com um $(X)$ se cada situação descrita é VERDADEIRA ou FALSA

Mark with an (X) whether each of the following situations is True or False.

VERDADE FaLso

Fiz mais de 50 testes no computador como preparação para hoje ............. $\square \ldots \ldots \ldots \ldots \ldots . \square$

As a preparation for today I did more than 50 computer (at home) tests

Fui fazendo testes à medida que ía assistindo às aulas teóricas

I did practice tests during the entire time I was taking theory lessons

Usei o livro de código para perceber melhor os meus erros nos testes ........ $\square \ldots \ldots \ldots \ldots \ldots . \ldots$

I used the "Rules of the Road" book to better understand my mistakes on those tests

Fui a mais aulas teóricas do que o mínimo exigido

I attended more theory lessons than the minimum required

Preparei a matéria das aulas teóricas antes de ir assistir às aulas

I prepared the lessons' material before attending the lessons

Tirei apontamentos nas aulas teóricas

I took notes during the theory lessons

Tirei dúvidas com o instrutor várias vezes

I asked the instructor for clarification several times

Acho que não é preciso estudar muito para o exame teórico

I don't think one needs to study very hard for the theory exam

6. Quantas aulas práticas (de condução) já completou até à data de hoje?

How many practice lessons (on-the-road) have you completed

before today?

7. Acha que vai passar à primeira no exame prático (de condução)?

Do you think you will pass the driving exam at first try?

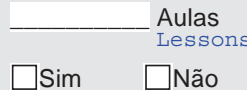

8. Data de nascimento:

9. Sexo:

$\square$ Feminino

$\square$ Masculino

Date of birth

Gender

10. (OPCIONAL) Caso não se importe de ser contactado posteriormente para perguntas adicionais referentes ao exame por favor indique o seu endereço de email

(OPTIONAL) Please provide your email address if we can contact you with additional

questions regardingE-mail:

the exam.

Obrigado pela sua colaboração!

Thank you very much! 
Table 1: Summary Statistics, Municipality Characteristics, Sample Markets $(N=214)$

\begin{tabular}{lrrrrr}
\hline & Mean & Std Dev & Min & Med & Max \\
\hline Number of schools & 3.224 & 3.271 & 1.000 & 2.000 & 22.000 \\
Number of students & 422.645 & 560.059 & 30.000 & 236.500 & 3353.000 \\
Population (000) & 27.158 & 32.206 & 2.952 & 15.700 & 181.474 \\
\hline Share of population in urban parishes & 80.014 & 21.989 & 15.489 & 87.796 & 100.000 \\
Mean per-capita income (€) & 861.254 & 113.706 & 616.600 & 867.400 & 1519.400 \\
Share with higher education (parish) & 12.789 & 5.173 & 4.028 & 11.300 & 29.105 \\
Number of parishes in muni & 24.814 & 20.969 & 1.000 & 18.000 & 89.000 \\
Number of car repair shops & 62.030 & 55.415 & 0.000 & 40.000 & 214.000 \\
Average monthly rent (€) & 137.204 & 31.457 & 47.000 & 140.200 & 257.250 \\
Share non-residential buildings & 8.858 & 3.094 & 3.260 & 8.680 & 27.740 \\
\hline
\end{tabular}

Note: Relevant statistics are student weighted. Mean income is monthly wage income of fulltime employees.

Table 2: Summary Statistics, School and Examiner Characteristics

\begin{tabular}{lrrrrr}
\hline & Mean & Std Dev & Q25 & Med & Q75 \\
\hline Number of students & 142.211 & 83.677 & 87.000 & 122.000 & 176.000 \\
Number of instructors & 5.751 & 3.759 & 3.000 & 5.000 & 7.000 \\
Instructor experience (years) & 8.044 & 5.417 & 4.202 & 6.458 & 10.214 \\
Number of vehicles & 3.822 & 2.359 & 3.000 & 3.000 & 4.000 \\
Median weight of fleet cars $(000 \mathrm{~kg})$ & 1.195 & 0.105 & 1.130 & 1.185 & 1.261 \\
\hline Distance to exam center $(\mathrm{km})$ & 21.142 & 17.893 & 5.619 & 17.883 & 30.081 \\
Number of examiners per center & 8.054 & 4.941 & 4.000 & 7.000 & 12.000 \\
Examiner experience $($ exams $/$ month) & 57.892 & 18.914 & 48.308 & 57.131 & 69.944 \\
Distance to IMTT office $(\mathrm{km})$ & 23.369 & 17.481 & 10.738 & 20.620 & 35.623 \\
\hline Price, base course $(€)$ & 705.900 & 110.424 & 625.000 & 700.000 & 775.000 \\
Price, theory course repeat $(€)$ & 129.080 & 26.288 & 110.330 & 130.000 & 150.000 \\
Price, on-road course repeat $(€)$ & 275.209 & 47.076 & 250.000 & 275.880 & 305.000 \\
\hline
\end{tabular}

Note: Observations: 636 schools, 26 exam centers, and 185 examiners. All statistics are student weighted. 
Table 3: Summary Statistics, Student Attributes $(N=90,446)$

\begin{tabular}{lrrrrr}
\hline & Mean & Std Dev & Q25 & Med & Q75 \\
\hline Age at time of theory exam (years) & 21.876 & 6.771 & 18.349 & 19.072 & 21.812 \\
Gender (1=F, 0=M) & 0.510 & 0.500 & 0.000 & 1.000 & 1.000 \\
Distance to city center (km) & 4.644 & 3.872 & 1.482 & 3.780 & 6.824 \\
Distance to school (km) & 4.874 & 6.007 & 1.007 & 2.875 & 6.268 \\
Theory exams taken (number) & 1.371 & 0.812 & 1.000 & 1.000 & 1.000 \\
On-road exams taken (number) & 1.360 & 0.688 & 1.000 & 1.000 & 2.000 \\
Pass rate, first theory exam (\%) & 75.988 & 42.716 & 100.000 & 100.000 & 100.000 \\
Pass rate, first on-road exam (\%) & 73.226 & 44.278 & 0.000 & 100.000 & 100.000 \\
Time to completion (days) & 250.116 & 150.527 & 143.000 & 211.000 & 315.000 \\
Choice is closest school (1=Y, 0=N) & 0.464 & 0.499 & 0.000 & 0.000 & 1.000 \\
\hline
\end{tabular}

Table 4: Relative Prices and Estimated Markups for Base and Repeat Courses

\begin{tabular}{lrrrrr}
\hline & Mean & Std Dev & Q25 & Med & Q75 \\
\hline Ratio, repeat to base fees & 0.585 & 0.117 & 0.500 & 0.587 & 0.667 \\
\hline Markup, base course $(€)$ & 203.590 & 111.777 & 124.302 & 199.200 & 279.150 \\
Markup, theory course repeat $(€)$ & 112.712 & 26.111 & 95.000 & 113.797 & 133.000 \\
Markup, on-road course repeat $(€)$ & 161.369 & 45.908 & 132.427 & 162.689 & 194.120 \\
Effective markup $(€)$ & 304.544 & 124.782 & 207.438 & 298.191 & 398.307 \\
\hline Percent markup, base course & 0.272 & 0.124 & 0.196 & 0.286 & 0.361 \\
Percent markup, theory course repeat & 0.864 & 0.069 & 0.850 & 0.875 & 0.889 \\
Percent markup, on-road course repeat & 0.575 & 0.080 & 0.533 & 0.589 & 0.630 \\
Percent effective markup & 0.327 & 0.106 & 0.263 & 0.337 & 0.405 \\
\hline
\end{tabular}

Note: The effective markup is the average total markup across a school's students. 
Table 5: Regression Models of Base Course Prices

\begin{tabular}{|c|c|c|c|c|}
\hline & \multicolumn{2}{|c|}{ OLS } & \multicolumn{2}{|c|}{ IV } \\
\hline & (1) & $(2)$ & $(3)$ & $(4)$ \\
\hline Number of firms $(N)$ & $\begin{array}{c}-9.524^{* *} \\
(4.190)\end{array}$ & & $\begin{array}{c}-10.874^{* *} \\
(5.293)\end{array}$ & \\
\hline$(N=2) \mathrm{Y} / \mathrm{N}$ & & $\begin{array}{r}-28.155^{*} \\
(15.818)\end{array}$ & & $\begin{array}{c}-26.390 \\
(17.938)\end{array}$ \\
\hline$(N=3) \mathrm{Y} / \mathrm{N}$ & & $\begin{array}{c}-31.531 \\
(20.077)\end{array}$ & & $\begin{array}{c}-32.467 \\
(23.412)\end{array}$ \\
\hline$(N=4) \mathrm{Y} / \mathrm{N}$ & & $\begin{array}{l}-55.937^{* *} \\
(24.269)\end{array}$ & & $\begin{array}{c}-56.327^{*} \\
(31.832)\end{array}$ \\
\hline$(N=5) \mathrm{Y} / \mathrm{N}$ & & $\begin{array}{c}-69.811^{* *} \\
(30.334)\end{array}$ & & $\begin{array}{l}-67.881^{* * *} \\
(25.442)\end{array}$ \\
\hline$(N \geq 6) \mathrm{Y} / \mathrm{N}$ & & $\begin{array}{l}-85.101^{* * *} \\
(29.120)\end{array}$ & & $\begin{array}{c}-84.558^{* *} \\
(33.311)\end{array}$ \\
\hline$\%$ fail both exams & $\begin{array}{c}-2.461^{* *} \\
(1.105)\end{array}$ & $\begin{array}{c}-2.581^{* *} \\
(1.115)\end{array}$ & $\begin{array}{c}-2.474^{* *} \\
(1.086)\end{array}$ & $\begin{array}{c}-1.683^{*} \\
(0.863)\end{array}$ \\
\hline Number of instructors & $\begin{array}{c}0.786 \\
(1.292)\end{array}$ & $\begin{array}{c}1.669 \\
(1.235)\end{array}$ & $\begin{array}{c}0.686 \\
(1.239)\end{array}$ & $\begin{array}{c}2.125 \\
(1.372)\end{array}$ \\
\hline Median weight of fleet cars (kg) & $\begin{array}{r}-0.013 \\
(0.035)\end{array}$ & $\begin{array}{r}-0.002 \\
(0.036)\end{array}$ & $\begin{array}{r}-0.013 \\
(0.034)\end{array}$ & $\begin{array}{c}0.020 \\
(0.028)\end{array}$ \\
\hline School $\leq 100 \mathrm{~m}$ to high school & $\begin{array}{l}48.488 \\
(39.767)\end{array}$ & $\begin{array}{l}50.206 \\
(39.137)\end{array}$ & $\begin{array}{l}48.319 \\
(39.236)\end{array}$ & $\begin{array}{c}41.008 \\
(31.304)\end{array}$ \\
\hline School distance to city center & $\begin{array}{l}3.827^{* * *} \\
(1.240)\end{array}$ & $\begin{array}{l}4.445^{* * *} \\
(1.315)\end{array}$ & $\begin{array}{c}3.862^{* * *} \\
(1.214)\end{array}$ & $\begin{array}{c}3.256^{* * *} \\
(0.798) \\
\end{array}$ \\
\hline$\%$ of population in urban parishes & $\begin{array}{c}-0.650^{*} \\
(0.346)\end{array}$ & $\begin{array}{c}-0.604^{*} \\
(0.318)\end{array}$ & $\begin{array}{c}-0.636^{*} \\
(0.348)\end{array}$ & $\begin{array}{c}-0.407^{*} \\
(0.360)\end{array}$ \\
\hline Per-capita income & $\begin{array}{c}0.109 \\
(0.076)\end{array}$ & $\begin{array}{l}0.152^{* *} \\
(0.075)\end{array}$ & $\begin{array}{c}0.107 \\
(0.076)\end{array}$ & $\begin{array}{r}-0.084^{*} \\
(0.046)\end{array}$ \\
\hline Number of car repair shops & $\begin{array}{c}-0.552^{* *} \\
(0.264)\end{array}$ & $\begin{array}{c}-0.588^{* *} \\
(0.286)\end{array}$ & $\begin{array}{c}-0.528^{*} \\
(0.278)\end{array}$ & $\begin{array}{c}0.729 \\
(0.515)\end{array}$ \\
\hline Population (000) & $\begin{array}{l}0.850^{* *} \\
(0.400) \\
\end{array}$ & $\begin{array}{c}0.326 \\
(0.367) \\
\end{array}$ & $\begin{array}{c}0.951^{* *} \\
(0.417) \\
\end{array}$ & $\begin{array}{r}-0.511 \\
(0.741) \\
\end{array}$ \\
\hline $\begin{array}{l}\text { Adjusted } R^{2} \\
1^{\text {st }} \text { stage partial } R^{2} \\
1^{\text {st }} \text { stage } F \text { statistic }\end{array}$ & 0.360 & 0.369 & $\begin{array}{r}0.360 \\
0.689 \\
16.614\end{array}$ & \\
\hline Observations & 636 & 636 & 636 & 636 \\
\hline
\end{tabular}

${ }^{*} \mathrm{p}<0.1,{ }^{* *} \mathrm{p}<0.05,{ }^{* * *} \mathrm{p}<0.01$. Municipality-level clustered standard errors in parentheses. Note: Specifications include region fixed effects and additional, statistically insignificant, controls (instructor experience and its square, distance to exam center, and a coastal area indicator). Models (3) and (4) use pre-deregulation firm count, distance to the closest IMT office, average rent and commercial building share as instruments. 
Table 6: Regression Models of Repeat Course Price

\begin{tabular}{|c|c|c|c|c|}
\hline & \multicolumn{2}{|c|}{ OLS } & \multicolumn{2}{|c|}{ IV } \\
\hline & (1) & $(2)$ & $(3)$ & $(4)$ \\
\hline Number of firms $(N)$ & $\begin{array}{c}-1.063 \\
(2.249)\end{array}$ & & $\begin{array}{c}-3.972 \\
(3.216)\end{array}$ & \\
\hline$(N=2) \mathrm{Y} / \mathrm{N}$ & & $\begin{array}{c}3.157 \\
(10.706)\end{array}$ & & $\begin{array}{c}7.672 \\
(10.690)\end{array}$ \\
\hline$(N=3) \mathrm{Y} / \mathrm{N}$ & & $\begin{array}{l}-5.246 \\
(12.440)\end{array}$ & & $\begin{array}{c}5.045 \\
(14.415)\end{array}$ \\
\hline$(N=4) \mathrm{Y} / \mathrm{N}$ & & $\begin{array}{l}-4.438 \\
(18.767)\end{array}$ & & $\begin{array}{l}-2.108 \\
(17.097)\end{array}$ \\
\hline$(N=5) \mathrm{Y} / \mathrm{N}$ & & $\begin{array}{r}-18.969 \\
(15.643)\end{array}$ & & $\begin{array}{r}-19.788 \\
(17.134)\end{array}$ \\
\hline$(N \geq 6) \mathrm{Y} / \mathrm{N}$ & & $\begin{array}{c}8.083 \\
(15.676)\end{array}$ & & $\begin{array}{c}14.587 \\
(24.098)\end{array}$ \\
\hline$\%$ fail both exams & $\begin{array}{r}-0.444 \\
(0.583) \\
\end{array}$ & $\begin{array}{r}-0.468 \\
(0.574)\end{array}$ & $\begin{array}{r}-0.473 \\
(0.585) \\
\end{array}$ & $\begin{array}{c}0.092 \\
(0.716) \\
\end{array}$ \\
\hline Number of instructors & $\begin{array}{l}4.210^{* * *} \\
(0.839)\end{array}$ & $\begin{array}{l}4.330^{* * *} \\
(0.863)\end{array}$ & $\begin{array}{l}3.993^{* * *} \\
(0.818)\end{array}$ & $\begin{array}{l}3.164^{* * *} \\
(0.935)\end{array}$ \\
\hline Median weight of fleet cars $(\mathrm{kg})$ & $\begin{array}{l}0.078^{* * *} \\
(0.023)\end{array}$ & $\begin{array}{l}0.076^{* * *} \\
(0.023)\end{array}$ & $\begin{array}{l}0.078^{* * *} \\
(0.023)\end{array}$ & $\begin{array}{l}0.049^{* * *} \\
(0.023)\end{array}$ \\
\hline School $\leq 100 \mathrm{~m}$ to high school & $\begin{array}{l}55.726^{* * *} \\
(20.359)\end{array}$ & $\begin{array}{l}55.475^{* * *} \\
(20.991)\end{array}$ & $\begin{array}{l}55.362^{\text {*** }} \\
(19.926)\end{array}$ & $\begin{array}{c}50.728^{* *} \\
(25.737)\end{array}$ \\
\hline School distance to city center & $\begin{array}{c}1.776^{* *} \\
(0.848)\end{array}$ & $\begin{array}{c}1.993^{* *} \\
(0.897)\end{array}$ & $\begin{array}{c}1.852^{* *} \\
(0.832) \\
\end{array}$ & $\begin{array}{c}1.142^{*} \\
(0.604) \\
\end{array}$ \\
\hline$\%$ of population in urban parishes & $\begin{array}{c}-0.572^{* * *} \\
(0.169)\end{array}$ & $\begin{array}{c}-0.521^{* * *} \\
(0.171)\end{array}$ & $\begin{array}{c}-0.541^{* * *} \\
(0.167)\end{array}$ & $\begin{array}{c}-0.634^{* * *} \\
(0.217)\end{array}$ \\
\hline Per-capita income & $\begin{array}{c}0.012 \\
(0.040)\end{array}$ & $\begin{array}{c}0.011 \\
(0.041)\end{array}$ & $\begin{array}{c}0.006 \\
(0.040)\end{array}$ & $\begin{array}{c}-0.017 \\
(0.038)\end{array}$ \\
\hline Number of car repair shops & $\begin{array}{l}0.487^{* * *} \\
(0.122)\end{array}$ & $\begin{array}{c}0.453^{* * *} \\
(0.136)\end{array}$ & $\begin{array}{l}0.540^{* * *} \\
(0.126)\end{array}$ & $\begin{array}{c}0.298 \\
(0.350)\end{array}$ \\
\hline Population (000) & $\begin{array}{r}-0.459^{*} \\
(0.247) \\
\end{array}$ & $\begin{array}{c}-0.621^{* * *} \\
(0.155)\end{array}$ & $\begin{array}{c}-0.242 \\
(0.328) \\
\end{array}$ & $\begin{array}{r}-0.431 \\
(0.351) \\
\end{array}$ \\
\hline $\begin{array}{l}\text { Adjusted } R^{2} \\
1^{\text {st }} \text { stage partial } R^{2} \\
1^{\text {st }} \text { stage } F \text { statistic }\end{array}$ & 0.145 & 0.153 & $\begin{array}{r}0.141 \\
0.689 \\
16.614\end{array}$ & \\
\hline Observations & 636 & 636 & 636 & 636 \\
\hline
\end{tabular}

${ }^{*} \mathrm{p}<0.1,{ }^{* *} \mathrm{p}<0.05,{ }^{* * *} \mathrm{p}<0.01$. Municipality-level clustered standard errors in parentheses. Note: See notes to Table 5 . 
Table 7: Expectations of Financial Repercussions of Failing Theory Exam, Survey Respondents

\begin{tabular}{lrcc}
\hline & \multicolumn{3}{c}{ Share of Respondents } \\
\cline { 2 - 4 } & \multicolumn{1}{c}{ All } & Female & Male \\
\hline No & 4.091 & 3.070 & 5.189 \\
Do not know & 17.500 & 14.912 & 20.283 \\
Yes, but do not know how much & 26.364 & 25.439 & 27.358 \\
Yes, and know how much & 52.045 & 56.579 & $47.170^{* *}$ \\
\hline
\end{tabular}

Note: Breakdown of responses of 440 survey participants to question "In case you fail, will you have to pay your school to retake the theory exam?". P-values for test of equality of male and female shares of respondents indicated as ${ }^{*} \mathrm{p}<0.1,{ }^{* *} \mathrm{p}<0.05,{ }^{* * *} \mathrm{p}<0.01$.

Table 8: Comparison of Expected and Actual Exam Outcomes, Survey Respondents

\begin{tabular}{lccccc}
\hline & \multicolumn{2}{c}{ Theory } & & \multicolumn{2}{c}{ On-Road } \\
\cline { 2 - 3 } \cline { 5 - 5 } & & $\begin{array}{c}\text { Mean Difference, } \\
\text { Expectation less }\end{array}$ & & $\begin{array}{c}\text { Mean Difference, } \\
\text { Expectation less } \\
\text { Pass Rate }\end{array}$ & $\begin{array}{c}\text { Excidence of Passing } \\
\text { Incidence of Passing }\end{array}$ \\
\hline Overall & 0.725 & -0.034 & & 0.766 & $0.100^{* * *}$ \\
Female & 0.711 & $-0.083^{* *}$ & & 0.739 & $0.075^{*}$ \\
Male & 0.741 & 0.019 & & 0.792 & $0.126^{* * *}$ \\
Informed & 0.733 & -0.035 & & 0.786 & $0.089^{* * *}$ \\
Uninformed & 0.695 & -0.032 & 0.683 & $0.143^{* *}$ \\
\hline
\end{tabular}

Note: Informed students: Expect to pay for exam retake $=\mathrm{Y}$. P-values indicated as $* \mathrm{p}<0.1$, ** $\mathrm{p}<0.05,{ }^{* * *} \mathrm{p}<0.01$. The shares of female and informed students for the theory (on-road) exam comparison is $51.82 \%$ and $78.41 \%$ ( $50.31 \%$ and $80.31 \%$ ). There is no statistically significant difference at the $5 \%$ level between female and male or informed and uninformed students' pass rates in the theory exam. Informed students have higher pass rates than uninformed students in the on-road exam at the $5 \%$ level. 
Table 9: Exam Preparation by Student Type, Survey Respondents

\begin{tabular}{lccc}
\hline & \multicolumn{2}{c}{ Share of "Yes" Responses } & \\
\cline { 2 - 3 } & Informed & Uninformed & p-Value \\
\hline More than 50 practice exams taken & 0.722 & 0.628 & 0.047 \\
Practice exams taken consistently throughout course & 0.764 & 0.779 & 0.612 \\
Use of book to understand errors in practice exams & 0.889 & 0.826 & 0.057 \\
Sitting in extra lessons & 0.605 & 0.631 & 0.668 \\
Preparation of material prior to class & 0.168 & 0.108 & 0.092 \\
Note taking during class & 0.709 & 0.643 & 0.122 \\
Frequent engagement with instructor & 0.807 & 0.845 & 0.784 \\
\hline
\end{tabular}

Note: Items listed correspond to block of items in Question 5 concerning the extent of exam preparation (see questionnaire in Figure 5). P-values are for the tests of equality of preparation (shares of "Yes" responses) for informed and uninformed students versus the hypotheses that informed students engage in more preparation than uninformed students. 


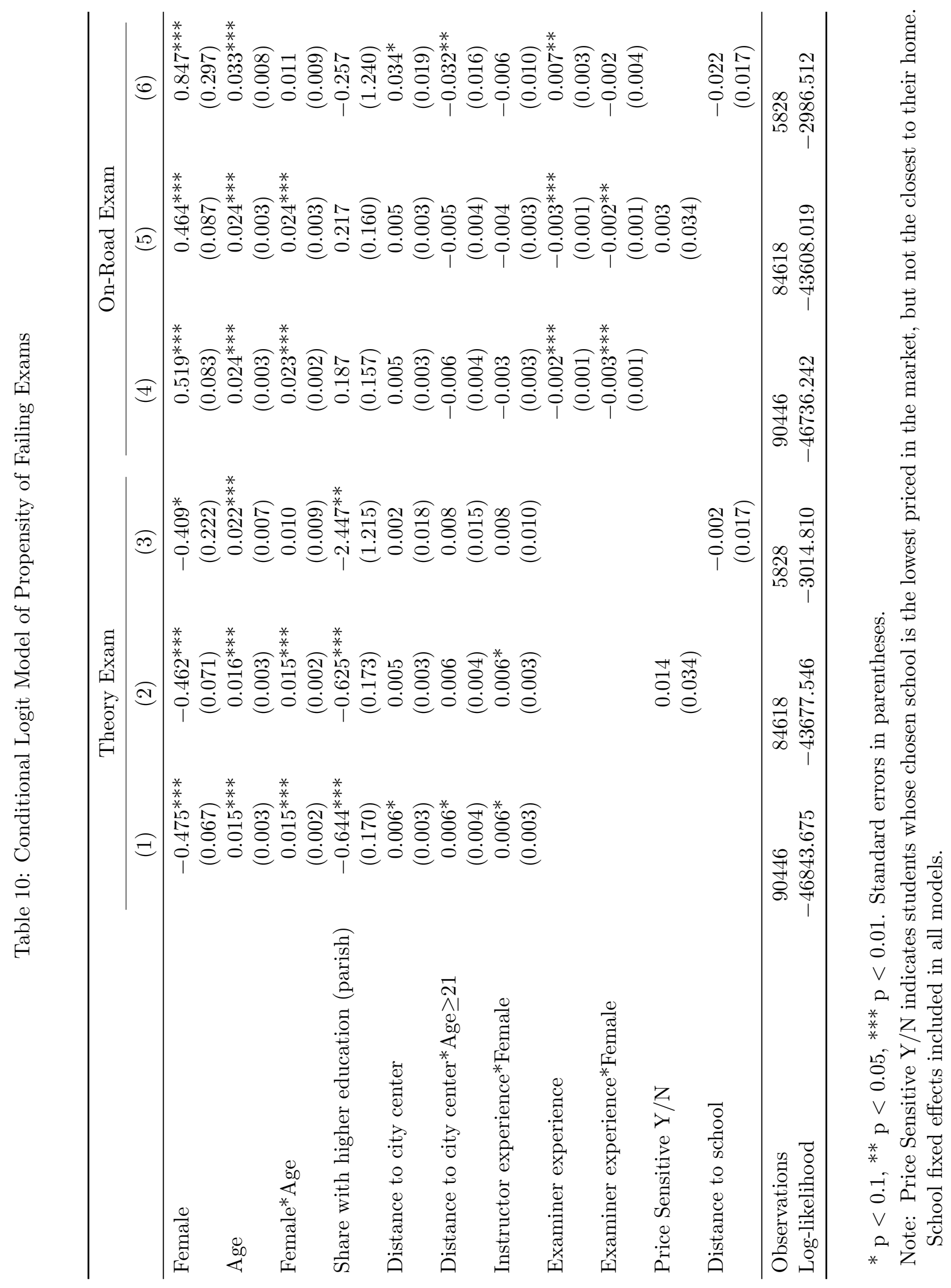




\section{Appendix}

\section{A Equilibrium in Illustrative Model in Section 2}

In this Appendix we establish the equilibrium of the add-on pricing model in Section 2 . Here, we assume that the full menu of prices is observable to consumers; inattentive students simply choose not to take add-on prices into account when making their school choice. In the following section we establish that, in contrast to markets where the add-on is avoidable, there is no profit gain to the firm from shrouding add-on prices. Recall the properties of the equilibrium summarized in (3):

Suppose there are $n$ schools that offer an upfront service for price $p^{u}$ at cost $c^{u}$ and an add-on service for price $p^{a}$ at cost $c^{a}$, and that there are a continuum of students. Let the fraction of sophisticates in the student population be $\pi \in(0,1)$ and the fraction of students who fail the exam be $\bar{\lambda} \in(0,1]$. If students fail the exam, they must buy the add-on service in period 2. There is a unique symmetric Nash equilibrium in which sophisticates engage in effort to lower their probability of failing to $\underline{\lambda}$ and, in period 1, schools charge an upfront price of

$$
\left(p^{u}\right)^{*}=c^{u}+\frac{\sigma n}{n-1}-[(1-\pi) \bar{\lambda}+\pi \underline{\lambda}]\left(\bar{p}^{a}-c^{a}\right)
$$

while, in period 2, they charge an add-on price of

$$
\left(p^{a}\right)^{*}=\bar{p}^{a}>c^{a} .
$$

Consider first the school's choice of add-on price, $p^{a}$. In the second period, school $j$ sells the add-on service to $\pi$ sophisticated and $(1-\pi)$ inattentive students and earns profit of

$$
\begin{gathered}
\Pi_{j}=\pi\left[p_{j}^{u}-c^{u}+\underline{\lambda}\left(p_{j}^{a}-c^{a}\right)\right] D^{s}\left(p_{-j}^{u}-p_{j}^{u}+\underline{\lambda}\left(p_{-j}^{a}-p_{j}^{a}\right)\right)+ \\
(1-\pi)\left[p_{j}^{u}-c^{u}+\bar{\lambda}\left(p_{j}^{a}-c^{a}\right)\right] D^{m}\left(p_{-j}^{u}-p_{j}^{u}\right)
\end{gathered}
$$

where we express the school's demand, $\left\{D^{m}, D^{s}\right\}$, in $(2)$ only as a function of the price arguments.

Given that the add-on price, $p^{a}$, does not shift the demand of the inattentive students, it is optimal for the firm to set it at the highest possible level, $\bar{p}^{a}$. A lower add-on price would not be profit-maximizing: for any combination of competitor prices, $\left\{p_{-j}^{u}, p_{-j}^{a}\right\}$, the firm could raise its add-on price by $\Delta$ and lower its upfront price by $\underline{\lambda} \Delta$. This would leave the demand and per-student revenue earned on sophisticated students unchanged. It would, however, increase both the demand from inattentive students through the decline in the upfront price and - provided $\bar{\lambda}>\underline{\lambda}$ - the revenue per inattentive student 25

\footnotetext{
${ }^{25}$ If $\bar{\lambda}<\underline{\lambda}$, a similar argument results from raising the add-on price by $\Delta$ and lowering the upfront price by $\bar{\lambda} \Delta$.
} 
The firm's upfront price $p_{u}$ then maximizes:

$$
\Pi_{j}=\left\{p_{j}^{u}-c^{u}+[\pi \underline{\lambda}+(1-\pi) \bar{\lambda}]\left(\bar{p}_{a}-c^{a}\right)\right\} D^{m}\left(p_{-j}^{u}-p_{j}^{u}\right) .
$$

Since schools are symmetric and charge the same add-on price in equilibrium, relative differences in add-on prices do not affect the sophisticated students' school choice. As a result, at the optimal add-on prices, their demand equals the inattentive students' demand, $D^{m}$. Solving the first-order condition to the firm's upfront pricing problem results in equilibrium prices of:

$$
\left(p^{u}\right)^{*}=c^{u}+\frac{\sigma n}{n-1}-[(1-\pi) \bar{\lambda}+\pi \underline{\lambda}]\left(\bar{p}^{a}-c^{a}\right) .
$$

This exposition assumes that sophisticated students find it in their best interest to engage in costly effort to reduce their probability of failing to $\underline{\lambda}$. Such effort is not necessarily efficient. The firm foregoes profit in the amount of $\left(\bar{p}^{a}-c^{a}\right)(\bar{\lambda}-\underline{\lambda})$ on every sophisticate. The choice to engage in effort, thus, is only efficient if $e \leq c^{a}(\bar{\lambda}-\underline{\lambda})$, whereas the student's choice to do so reflects the prices he pays for, rather than the cost of providing, the add-on service. Students will engage in effort provided the cost savings from engaging in effort, $(\bar{\lambda}-\underline{\lambda}) \bar{p}^{a}$, exceed the cost of effort $e$. Otherwise, the optimal upfront price simplifies to:

$$
\left(p^{u}\right)^{*}=c^{u}+\frac{\sigma n}{n-1}-\bar{\lambda}\left(\bar{p}^{a}-c^{a}\right)
$$

Equation (A.4) also illustrates the profit-neutrality inherent in the add-on pricing model with symmetric types. In equilibrium, with equal probabilities of failing across types, the firm earns expected revenue per student of

$$
\left(p^{u}\right)^{*}+\bar{\lambda} \bar{p}^{a}=c^{u}+\bar{\lambda} c^{a}+\frac{\sigma n}{n-1}
$$

The same level of revenue would result in a pricing game where firms serve only sophisticated students who account for both the upfront and the add-on services in their school choice. Then, the firm's profit function would be:

$$
\Pi_{j}=\left[p_{j}^{u}+\bar{\lambda} p_{j}^{a}-\left(c^{u}+\bar{\lambda} c^{a}\right)\right] D^{s}\left(p_{-j}^{u}-p_{j}^{u}+\bar{\lambda}\left(p_{-j}^{a}-p_{j}^{a}\right)\right)
$$

In the absence of inattentive types, there is no unique solution to the firm's pricing problem to pin down $\left(p^{u}\right)^{*}$ and $\left(p^{a}\right)^{*}$ if firms commit to prices in the first period. Only the expected per-student revenue is uniquely identified; it equals the expected revenue in A.5. Add-on pricing in the presence of inattentive students thus does not change the total amount of revenue a school earns from a student in expectation. It does, however, pin down how that revenue is distributed over the two services, placing a higher monetary burden on exam repeaters. 
Note also that with unavoidable add-ons and no cost to unshrouding prices, it can be shown that the firm is indifferent between shrouding and unshrouding. This result differs from the equilibrium derived in Gabaix and Laibson (2006) for the case of avoidable add-ons ${ }^{26}$ here, since sophisticated consumers know that they cannot substitute away from the add-on for certain and expect the add-on's price to equal the walk-away price, there is no gain to shrouding. While the shrouded equilibrium would be the optimal choice if there were even a small cost to unshrouding and releasing the add-on price to sophisticated consumers, our exposition in Section 2 relies on the unshrouded equilibrium for simplicity.

\section{B Calculation of Marginal Costs}

In this Appendix, we describe how we compute marginal costs for the schools' three services.

The base course marginal cost comprises five cost components: the fees paid to the exam center for the theory and on-road exams ( $F^{T}$ and $F^{P}$, respectively), the cost of the instructional materials the school provides to the student $(M)$, the instructor wages $(W)$, and the cost of operating a fleet car $(V)$ for a student's practice lessons. The theory repeat course generates as cost only the exam center fee for an examination. The on-road repeat course involves additional driving lessons with associated scaled-down wage and vehicle operating costs, in addition to the exam center's fee. Accordingly, we specify the marginal costs, $M C^{s}$, for service $s=\{U, T, P\}$ as:

$$
\begin{aligned}
M C^{U} & =F^{T}+F^{P}+M+W+(700+2 D) V \\
M C^{T} & =F^{T} \\
M C^{P} & =F^{P}+\frac{6}{33} W+\left(\frac{6}{33} \cdot 700+2 D\right) V,
\end{aligned}
$$

and compute each cost component as follows:

1. Exam administration fees $\left(F^{T}\right.$ and $\left.F^{P}\right) \quad$ The IMT provided us with information on each of the 25 exam centers' fees for administering the theory and on-road exams. We use the administration fees of the exam center used by the school, or a weighted average of fees if the school uses multiple exam centers.

2. Instructional materials expenses $(M) \quad$ The IMT and ANIECA quote $€ 10$ for instructional materials (driver handbooks and CD-ROMs).

3. Instructor wages $(W)$ Based on interviews with ANIECA and school representatives, an instructor's monthly salary ranges between $€ 750$ and $€ 950$. We assume that instructor salaries are proportional

${ }^{26}$ A number of authors, including Miao (2010), Kosfeld and Schüwer (2016), Heidhues et al. (2016), and Shulman and Geng (2013) have confirmed the results in Gabaix and Laibson (2006) in more general settings. 
to mean monthly earnings in the school's municipality across municipalities. We gross up the salary to include 23.75 percent social security tax and a $€ 3.4$ per diem stipend.

Since each student's base and on-road repeat courses include 32 and five driving lessons, respectively, we convert the monthly salary figure to an hourly basis based on ANIECA information on length of working days and number of days worked per month. We assume that schools incur only fixed, and not marginal, costs for the student's classroom time since schools rarely operate at capacity. The resulting marginal labor cost averages to $€ 235.63$ and only $€ 42.84$ for the base and repeat courses, respectively.

4. Vehicle operating costs $[(700+2 D) V]$ We follow existing methodologies for computing a vehicle's user cost in Portugal, comprised of (i) fuel costs, (ii) depreciation costs, (iii) maintenance and repairs costs, and (iv) tire costs. For the base course, we scale this user cost per kilometer, $V$, by twice the return distance to the exam center plus the 700 kilometers that school owners state are covered during lessons; for the repeat course, the latter amounts to only 127 kilometers. The sources of data for the individual cost components are:

- Fuel costs. We measure fuel costs as the average local price per liter of diesel fuel (obtained from the Direç̧ão-Geral de Energia e Geologia on March 12, 2012 for each of the five lowest priced stations per municipality), times fuel consumption per kilometer. ANIECA and school owners state typical consumption rates of 6.36 liters per $100 \mathrm{~km}$.

- Depreciation costs. We follow existing methodologies whereby a vehicle depreciates fully by 8.4 years and has a purchase price of $€ 25,000$, on average. This, together with information on the average distance traveled by a fleet car per year, yields an estimate of cost-per-kilometer driven.

- Maintenance and repair costs. We use public estimates of an average maintenance and repair cost of $€ 4,000$ over the car's service life, which we adjust to reflect fleet characteristics relative to the average car in the sample, and convert it to an estimate of cost per kilometer driven based on the annual distance traveled and a life of 8.4 years.

- Tire costs. We assume that the average car requires four new tires for every 40,000 kilometers at a cost of $€ 70$ per tire, which translates into an average tire cost of $€ .01$ per kilometer

The vehicle operating cost requires an estimate of the annual distance covered per vehicle. We use each school's data on kilometers covered per vehicle-year, as reported to the IMT, as an input to calculate each school's marginal cost for its base and repeat courses as in Equation (B.1). Table B.1 summarizes the inputs into the cost calculation and the resulting totals.

As a robustness check in case of measurement error, we recalculate marginal costs and markups using the median distance covered across all fleet cars of 20,358 kilometers per vehicle-year for all schools. This 
Table B.1: Marginal Cost Components for All Services (€, $N=636$ )

\begin{tabular}{lrrrrr}
\hline & Mean & Std Dev & Q25 & Med & Q75 \\
\hline Base Course & & & & & \\
Exam fees & 53.022 & 9.141 & 45.000 & 49.000 & 59.000 \\
Instructional materials & 10.000 & 0.000 & 10.000 & 10.000 & 10.000 \\
Instructor wages & 235.629 & 18.277 & 220.274 & 237.242 & 246.648 \\
Vehicle operating costs & 203.658 & 32.367 & 179.019 & 199.060 & 225.230 \\
& & & & & \\
Total & 502.309 & 40.763 & 470.815 & 498.768 & 529.892 \\
\hline Theory Repeat Course & & & & & \\
Theory exam fee & 16.368 & 1.868 & 15.000 & 15.384 & 17.000 \\
\hline On-road Repeat Course & & & & & \\
On-road exam fee & 36.650 & 7.346 & 30.000 & 33.429 & 42.000 \\
Instructor wages & 42.842 & 3.323 & 40.050 & 43.135 & 44.845 \\
Vehicle operating costs & 34.349 & 5.990 & 30.045 & 33.844 & 37.625 \\
& & & & & \\
Total & 113.841 & 10.615 & 105.125 & 112.932 & 121.080 \\
\hline
\end{tabular}

alternative marginal cost measure averages to $€ 493.55$ for the upfront service and $€ 112.42$ for the on-road repeat course. The markup patterns in Figure 3 and regression results in Tables D.1 and D.2 are robust to using this alternative marginal cost.

\section{Nonlinear Specification Estimation Procedure}

In this Appendix, we describe the full information maximum likelihood (FIML) procedure we use to control for the endogeneity of the discrete market structure indicators in the nonlinear price regressions describe in Section 4.3 .

We assume that school $i$ 's price in market $m$ is a function of observable market attributes, $\mathbf{X}^{\mathbf{1}}$, market and school specific variables, $\mathbf{X}^{2}$, market structure indicators $\gamma_{j m}^{P}$, and a school and market specific unobservable, $\xi$ :

$$
p_{i m}^{P}=\alpha^{P}+\beta^{P, 1} \mathbf{X}_{m}^{1}+\beta^{P, 2} \mathbf{X}_{i m}^{2}+\sum_{j=2}^{6} \gamma_{j m}^{P} \mathbb{1}_{\left\{\Pi_{m}^{E}=j\right\}}+\xi_{i m}^{P}=f^{P}\left(\mathbf{X}_{m}^{1}, \mathbf{X}_{i m}^{2}, \beta^{\mathbf{P}}\right)
$$

We assume the unobservable can be decomposed into $\xi_{i m}^{P}=\varepsilon_{m}^{P}+\eta_{i m}^{P}$, where $\varepsilon_{m}^{P}$ is a common error component shared by all schools in market $m$ and $\eta_{i m}^{P}$ is the school-specific error term with $\eta_{i m}^{P} \sim N\left(0, \sigma_{\eta, P}^{2}\right)$.

We specify the number of schools in market $m$, which ranges from 1 to 6 in the data, as an ordered 
probit model $[27$

$$
\Pi_{m}^{E}=\left\{\begin{array}{cc}
1 & \text { if } \alpha^{E}+\beta^{E, 1} \mathbf{X}_{m}^{1}+\beta^{E, 2} \mathbf{Z}_{m}+\varepsilon_{m}^{E}<\zeta_{1}^{E} \\
j & \text { if } \zeta_{j}^{E}<\alpha^{E}+\beta^{E, 1} \mathbf{X}_{m}^{1}+\beta^{E, 2} \mathbf{Z}_{m}+\varepsilon_{m}^{E}<\zeta_{j+1}^{E} \text { for } j=2, . ., 5 \\
6 & \text { if } \alpha^{E}+\beta^{E, 1} \mathbf{X}_{m}^{1}+\beta^{E, 2} \mathbf{Z}_{m}+\varepsilon_{m}^{E}>\zeta_{6}^{E},
\end{array}\right.
$$

where the parameter $\zeta_{j}^{E}$ implies a cutoff for the unobservable $\varepsilon_{m}^{E}$ between $j-1$ and $j$ schools and $\mathbf{Z}_{m}^{E}$ contains market-specific attributes that are excluded from the pricing equation.

We assume that $\varepsilon_{m}^{P}$ and $\varepsilon_{m}^{E}$ are distributed bivariate normal as follows:

$$
\left(\begin{array}{c}
\varepsilon_{m}^{P} \\
\varepsilon_{m}^{E}
\end{array}\right) \sim N\left(\left(\begin{array}{l}
0 \\
0
\end{array}\right),\left(\begin{array}{cc}
\sigma_{P}^{2} & \sigma_{E P} \\
\sigma_{E P} & 1
\end{array}\right)\right)
$$

The covariance terms allow for correlations in the market-level unobservables that give rise to endogeneity concerns, with $\sigma_{E P}$ and $\sigma_{P}$ parameters to be estimated.

In estimating the nonlinear system of equations, the contribution of the likelihood from market $m$ equals:

$$
L_{m}=\operatorname{Pr}\left(p_{i m}^{P}=p_{i} \forall i, \Pi_{m}^{E}=j\right)=\operatorname{Pr}\left(\xi_{i m}^{P}=p_{i}-f_{i}^{P} \forall i, \zeta_{j}^{E}-f^{E}<\varepsilon_{m}^{E}<\zeta_{j+1}^{E}-f^{E}\right)
$$

where $j$ is an index of the observed number of entrants, $p_{i m}$ is the observed price of school $i$, and $f^{E}\left(\mathbf{X}_{m}^{1}\right.$, $\left.\mathbf{Z}_{i m}, \beta^{\mathbf{E}}\right)=\alpha^{E}+\beta^{E, 1} \mathbf{X}_{m}^{1}+\beta^{E, 2} \mathbf{Z}_{m}$. This probability is given by the integral of the $2 N+1$-dimensional normal distribution of $\xi_{i m}^{P}$ and $\varepsilon_{m}^{E}$ with mean zero and variance-covariance matrix given by (where $\mathbf{I}$ is the identity matrix and $\boldsymbol{\Xi}$ is a matrix of ones)

$$
\boldsymbol{\Sigma}=\left[\begin{array}{cc}
\sigma_{P}^{2} \boldsymbol{\Xi}_{2 N \times 2 N}+\mathbf{I}_{2 N \times 2 N} & \sigma_{E P} \mathbf{I}_{2 N \times 1} \\
\sigma_{E P} \mathbf{I}_{1 \times 2 N} & 1
\end{array}\right]
$$

over the surface defined by $f^{P}$ and $f^{E}$ and the cutoffs $\zeta_{2}^{E}$ through $\zeta_{6}^{E}$ that are consistent with observed prices and the observed number of entrants, respectively. Note that $\boldsymbol{\Sigma}$ results from stacking the $2 N$ price equation errors $\xi_{i m}^{P}=\varepsilon_{m}^{P}+\eta_{i m}^{P}$ and the single market-level error, $\varepsilon_{m}^{E}$. We integrate out $\eta_{i m}^{P}$ to yield:

$$
L_{m}=\int_{\zeta_{j}^{E}-f^{E}}^{\zeta_{j+1}^{E}-f^{E}} \int_{-\infty}^{\infty}\left[\prod_{i=1}^{N} \phi\left(p_{i}-f_{i}^{P}-\varepsilon_{m}^{P}\right)\right] \phi\left(\varepsilon_{m}^{P}, \varepsilon_{m}^{E}\right) d \varepsilon_{m}^{P} d \varepsilon_{m}^{E}
$$

where

$$
g_{i}^{P}\left(\varepsilon_{m}^{P}\right)=\phi\left(p_{i}-f_{i}^{P}-\varepsilon_{m}^{P}\right)
$$

is the standard normal pdf of $\eta_{i m}^{P}$ and $\phi\left(\varepsilon_{m}^{P}, \varepsilon_{m}^{E}\right)$ refers to the pdf of the bivariate normal distribution of $\left(\varepsilon_{m}^{P}, \varepsilon_{m}^{E}\right)$ given by C.3.

\footnotetext{
${ }^{27}$ We combine markets with six or more schools into the final category.
} 
Conditioning on $\varepsilon_{m}^{P}$ and integrating over $\varepsilon_{m}^{E}$ results in:

$$
L_{m}=\int_{-\infty}^{\infty}\left[\prod_{i=1}^{N} g_{i}^{P}\left(\varepsilon_{m}^{P}\right)\right] \times\left[\Phi_{\varepsilon_{m}^{E} \mid \varepsilon_{m}^{P}}\left(\zeta_{j+1}^{E}-f^{E}\right)-\Phi_{\varepsilon_{m}^{E} \mid \varepsilon_{m}^{P}}\left(\zeta_{j}^{E}-f^{E}\right)\right] \phi\left(\varepsilon_{m}^{P}\right) d \varepsilon_{m}^{P}
$$

where $\Phi_{\varepsilon_{m}^{E}} \mid \varepsilon_{m}^{P}$ denotes the conditional cdf of $\varepsilon_{m}^{E}$, given realizations of $\varepsilon_{m}^{P}$.

For a given value of the parameters, we use simulation techniques to compute each market's contribution to the likelihood function by integrating numerically over the normal distribution of $\varepsilon_{m}^{P}$ and use a numerical optimizer to maximize the full likelihood:

$$
L=\prod_{m=1}^{M}\left\{\int_{-\infty}^{\infty}\left[\prod_{i=1}^{N} \frac{1}{\sigma_{\eta, P}} \phi\left(\frac{p_{i}-f_{i}^{P}-\varepsilon_{m}^{P}}{\sigma_{\eta, P}}\right)\right] \times\left[\Phi_{\varepsilon_{m}^{E} \mid \varepsilon_{m}^{P}}\left(\zeta_{j+1}^{E}-f^{E}\right)-\Phi_{\varepsilon_{m}^{E} \mid \varepsilon_{m}^{P}}\left(\zeta_{j}^{E}-f^{E}\right)\right] \phi\left(\varepsilon_{m}^{P}\right) d \varepsilon_{m}^{P}\right\}
$$

\section{Determinants of Markups}

Here, we supplement the regression analysis in Section 4.3 with regression models of estimated school markups to verify that our primary results are not driven by cost differences between schools and across markets that are reflected in price. Table D.1 reports results for base course markups; Table D.2 for repeat course markups, with similar patterns to the effect of competition and fail rates as in Tables 5 and 6 . 
Table D.1: Regression Models of Base Course Markups

\begin{tabular}{|c|c|c|c|c|}
\hline & \multicolumn{2}{|c|}{ OLS } & \multicolumn{2}{|c|}{ IV } \\
\hline & $(1)$ & $(2)$ & $(3)$ & $(4)$ \\
\hline Number of firms $(N)$ & $\begin{array}{c}-8.352^{*} \\
(4.347)\end{array}$ & & $\begin{array}{c}-9.841^{*} \\
(5.376)\end{array}$ & \\
\hline$(N=2) \mathrm{Y} / \mathrm{N}$ & & $\begin{array}{c}-40.872^{* *} \\
(16.714)\end{array}$ & & $\begin{array}{c}-40.563^{* *} \\
(17.798)\end{array}$ \\
\hline$(N=3) \mathrm{Y} / \mathrm{N}$ & & $\begin{array}{c}-52.347^{* *} \\
(20.366)\end{array}$ & & $\begin{array}{c}-56.324^{* *} \\
(24.375)\end{array}$ \\
\hline$(N=4) \mathrm{Y} / \mathrm{N}$ & & $\begin{array}{c}-79.795^{* * *} \\
(25.525)\end{array}$ & & $\begin{array}{c}-82.649^{* * *} \\
(28.115)\end{array}$ \\
\hline$(N=5) \mathrm{Y} / \mathrm{N}$ & & $\begin{array}{c}-70.509^{* *} \\
(29.722)\end{array}$ & & $\begin{array}{c}-72.192^{* * *} \\
(22.836)\end{array}$ \\
\hline$(N \geq 6) \mathrm{Y} / \mathrm{N}$ & & $\begin{array}{c}-93.160^{* * *} \\
(29.644)\end{array}$ & & $\begin{array}{c}-94.796^{* * *} \\
(27.680)\end{array}$ \\
\hline$\%$ fail both exams & $\begin{array}{c}-2.344^{* *} \\
(1.172)\end{array}$ & $\begin{array}{c}-2.494^{* *} \\
(1.148)\end{array}$ & $\begin{array}{c}-2.359^{* *} \\
(1.151)\end{array}$ & $\begin{array}{l}-1.785^{* *} \\
(0.880)\end{array}$ \\
\hline Number of instructors & $\begin{array}{c}0.230 \\
(1.409)\end{array}$ & $\begin{array}{c}0.971 \\
(1.350)\end{array}$ & $\begin{array}{c}0.119 \\
(1.350)\end{array}$ & $\begin{array}{c}1.834 \\
(1.325)\end{array}$ \\
\hline Median weight of fleet cars $(\mathrm{kg})$ & $\begin{array}{c}-0.159^{* * *} \\
(0.037)\end{array}$ & $\begin{array}{c}-0.140^{* * *} \\
(0.038)\end{array}$ & $\begin{array}{c}-0.159^{* * *} \\
(0.036)\end{array}$ & $\begin{array}{c}-0.102^{* * * *} \\
(0.033)\end{array}$ \\
\hline School within $100 \mathrm{~m}$ from high school & $\begin{array}{l}46.115 \\
(35.245)\end{array}$ & $\begin{array}{l}53.565 \\
(34.591)\end{array}$ & $\begin{array}{l}45.928 \\
(34.792)\end{array}$ & $\begin{array}{c}41.831 \\
(40.214)\end{array}$ \\
\hline School distance to city center & $\begin{array}{l}3.704^{* * *} \\
(1.237)\end{array}$ & $\begin{array}{l}4.278^{* * *} \\
(1.296)\end{array}$ & $\begin{array}{l}3.280^{* * *} \\
(1.214)\end{array}$ & $\begin{array}{l}4.278^{* * *} \\
(0.990)\end{array}$ \\
\hline$\%$ of population in urban parishes & $\begin{array}{c}-0.682^{* *} \\
(0.339)\end{array}$ & $\begin{array}{r}-0.555^{*} \\
(0.320)\end{array}$ & $\begin{array}{c}-0.666^{*} \\
(0.342)\end{array}$ & $\begin{array}{c}-0.360 \\
(0.354)\end{array}$ \\
\hline Per-capita income & $\begin{array}{c}-0.024 \\
(0.076)\end{array}$ & $\begin{array}{c}0.016 \\
(0.072)\end{array}$ & $\begin{array}{r}-0.027 \\
(0.076)\end{array}$ & $\begin{array}{c}0.003 \\
(0.007)\end{array}$ \\
\hline Number of car repair shops & $\begin{array}{c}-0.430 \\
(0.311)\end{array}$ & $\begin{array}{c}-0.454 \\
(0.331)\end{array}$ & $\begin{array}{c}-0.403 \\
(0.328)\end{array}$ & $\begin{array}{c}-0.013 \\
(0.331)\end{array}$ \\
\hline Population (000) & $\begin{array}{c}0.670 \\
(0.461)\end{array}$ & $\begin{array}{c}0.201 \\
(0.426)\end{array}$ & $\begin{array}{c}0.781^{*} \\
(0.449)\end{array}$ & $\begin{array}{c}0.001 \\
(0.001)\end{array}$ \\
\hline $\begin{array}{l}\text { Adjusted } R^{2} \\
1^{\text {st }} \text { stage partial } R^{2} \\
1^{\text {st }} \text { stage } F \text { statistic }\end{array}$ & 0.338 & 0.353 & $\begin{array}{r}0.337 \\
0.689 \\
16.614\end{array}$ & \\
\hline
\end{tabular}

${ }^{*} \mathrm{p}<0.1,{ }^{* *} \mathrm{p}<0.05,{ }^{* * *} \mathrm{p}<0.01$. Municipality-level clustered standard errors in parentheses. Note: For a list of suppressed controls and instruments, see footnote to Table 5. 
Table D.2: Regression Models of Repeat Course Markups

\begin{tabular}{|c|c|c|c|c|}
\hline & \multicolumn{2}{|c|}{ OLS } & \multicolumn{2}{|c|}{ IV } \\
\hline & (1) & $(2)$ & $(3)$ & $(4)$ \\
\hline Number of firms $(N)$ & $\begin{array}{c}-0.974 \\
(2.194)\end{array}$ & & $\begin{array}{r}-4.572 \\
(3.355)\end{array}$ & \\
\hline$(N=2) \mathrm{Y} / \mathrm{N}$ & & $\begin{array}{l}-2.820 \\
(10.450)\end{array}$ & & $\begin{array}{c}1.933 \\
(10.699)\end{array}$ \\
\hline$(N=3) \mathrm{Y} / \mathrm{N}$ & & $\begin{array}{c}-13.605 \\
(12.483)\end{array}$ & & $\begin{array}{l}-4.257 \\
(12.853)\end{array}$ \\
\hline$(N=4) \mathrm{Y} / \mathrm{N}$ & & $\begin{array}{c}-11.765 \\
(17.531)\end{array}$ & & $\begin{array}{l}-7.049 \\
(18.004)\end{array}$ \\
\hline$(N=5) \mathrm{Y} / \mathrm{N}$ & & $\begin{array}{c}-17.643 \\
(15.558)\end{array}$ & & $\begin{array}{c}-16.663 \\
(15.794)\end{array}$ \\
\hline$(N \geq 6) \mathrm{Y} / \mathrm{N}$ & & $\begin{array}{c}7.245 \\
(15.073)\end{array}$ & & $\begin{array}{c}15.219 \\
(21.776)\end{array}$ \\
\hline$\%$ fail both exams & $\begin{array}{c}-0.451 \\
(0.598)\end{array}$ & $\begin{array}{c}-0.467 \\
(0.581)\end{array}$ & $\begin{array}{c}-0.488 \\
(0.602)\end{array}$ & $\begin{array}{c}0.052 \\
(0.692)\end{array}$ \\
\hline Number of instructors & $\begin{array}{l}4.030^{* * *} \\
(0.865)\end{array}$ & $\begin{array}{l}4.131^{* * *} \\
(0.895)\end{array}$ & $\begin{array}{l}3.762^{\text {*** }} \\
(0.832)\end{array}$ & $\begin{array}{l}3.116^{* * *} \\
(0.900)\end{array}$ \\
\hline Median weight of fleet cars $(\mathrm{kg})$ & $\begin{array}{c}0.043^{*} \\
(0.022)\end{array}$ & $\begin{array}{l}0.045^{* *} \\
(0.022)\end{array}$ & $\begin{array}{c}0.043^{*} \\
(0.022)\end{array}$ & $\begin{array}{c}0.026 \\
(0.023)\end{array}$ \\
\hline School within $100 \mathrm{~m}$ from high school & $\begin{array}{l}57.899^{* * *} \\
(20.979)\end{array}$ & $\begin{array}{l}60.244^{* * *} \\
(21.563)\end{array}$ & $\begin{array}{l}53.438^{* *} \\
(20.494)\end{array}$ & $\begin{array}{l}60.244^{* * *} \\
(26.656)\end{array}$ \\
\hline School distance to city center & $\begin{array}{c}1.573^{*} \\
(0.850)\end{array}$ & $\begin{array}{r}1.727^{*} \\
(0.885)\end{array}$ & $\begin{array}{l}1.668^{* *} \\
(0.836)\end{array}$ & $\begin{array}{c}1.055^{*} \\
(0.610)\end{array}$ \\
\hline$\%$ of population in urban parishes & $\begin{array}{c}-0.566^{* * *} \\
(0.170)\end{array}$ & $\begin{array}{c}-0.493^{* * *} \\
(0.169)\end{array}$ & $\begin{array}{c}-0.528^{* * *} \\
(0.169)\end{array}$ & $\begin{array}{c}-0.590^{* * *} \\
(0.207)\end{array}$ \\
\hline Per-capita income & $\begin{array}{c}0.000 \\
(0.040)\end{array}$ & $\begin{array}{c}-0.002 \\
(0.040)\end{array}$ & $\begin{array}{c}-0.006 \\
(0.040)\end{array}$ & $\begin{array}{c}0.003 \\
(0.007)\end{array}$ \\
\hline Number of car repair shops & $\begin{array}{l}0.549^{* * *} \\
(0.131)\end{array}$ & $\begin{array}{l}0.508^{* * *} \\
(0.142)\end{array}$ & $\begin{array}{c}-0.614^{* * *} \\
(0.140)\end{array}$ & $\begin{array}{r}-0.033 \\
(0.037)\end{array}$ \\
\hline Population (000) & $\begin{array}{c}-0.495^{* *} \\
(0.250)\end{array}$ & $\begin{array}{c}-0.672^{* * *} \\
(0.162)\end{array}$ & $\begin{array}{c}-0.226 \\
(0.341)\end{array}$ & $\begin{array}{c}0.001 \\
(0.002)\end{array}$ \\
\hline $\begin{array}{l}\text { Adjusted } R^{2} \\
1^{\text {st }} \text { stage partial } R^{2} \\
1^{\text {st }} \text { stage } F \text { statistic }\end{array}$ & 0.127 & 0.137 & $\begin{array}{r}0.121 \\
0.689 \\
16.614\end{array}$ & \\
\hline
\end{tabular}

${ }^{*} \mathrm{p}<0.1,{ }^{* *} \mathrm{p}<0.05,{ }^{* * *} \mathrm{p}<0.01$. Municipality-level clustered standard errors in parentheses. Note: For a list of suppressed controls and instruments, see footnote to Table 5. 